\title{
Migration of contaminants through the unsaturated zone overlying the Hesbaye chalky aquifer in Belgium: a field investigation
}

\author{
Serge Brouyère*, Alain Dassargues ${ }^{1}$, Vincent Hallet $^{2}$ \\ Hydrogeology Group, Department of Georesources, Geotechnologies and Building Materials (GEOMAC), \\ Building B52/3, University of Liège, B-4000 Sart Tilman, Belgium
}

Received 14 April 2003; received in revised form 17 October 2003; accepted 31 October 2003

\begin{abstract}
This paper presents the results of a detailed field investigation that was performed for studying groundwater recharge processes and solute downward migration mechanisms prevailing in the unsaturated zone overlying a chalk aquifer in Belgium. Various laboratory measurements were performed on core samples collected during the drilling of boreholes in the experimental site. In the field, experiments consisted of well logging, infiltration tests in the unsaturated zone, pumping tests in the saturated zone and tracer tests in both the saturated and unsaturated zones. Results show that gravitational flows govern groundwater recharge and solute migration mechanisms in the unsaturated zone. In the variably saturated chalk, the migration and retardation of solutes is strongly influenced by recharge conditions. Under intense injection conditions, solutes migrate at high speed along the partially saturated fissures, downward to the saturated zone. At the same time, they are temporarily retarded in the almost immobile water located in the chalk matrix. Under normal recharge conditions, fissures are inactive and solutes migrate slowly through the chalk matrix. Results also show that concentration dynamics in the saturated zone are related to fluctuations of groundwater levels in the aquifer. A conceptual model is proposed to explain the hydrodispersive behaviour of the variably saturated chalk. Finally, the vulnerability of the chalk to contamination issues occurring at the land surface is discussed.
\end{abstract}

(C) 2003 Elsevier B.V. All rights reserved.

Keywords: Chalk; Loess; Solute transport; Tracer; Saturated zone; Unsaturated zone; Dual porosity-dual permeability

* Corresponding author. Tel.: +32-4366-2377; fax: +32-4366-9520.

E-mail address: Serge.Brouyere@ulg.ac.be (S. Brouyère).

${ }^{1}$ Also at the Department of Geology and Geography, KULeuven, Belgium.

${ }^{2}$ Now at the Department of Geology, Facultés Universitaires Notre-Dame de la Paix at Namur, Belgium. 


\section{Introduction}

The Hesbaye aquifer is located in the Senonian chalk formations of the Geer basin in the eastern part of Belgium. It provides annually 30 millions cubic meters of drinking water used to supply about 600,000 people. Since 1960 , nitrate concentrations have risen annually at a rate ranging from $0.1 \mathrm{mg} / 1\left(\mathrm{as} \mathrm{NO}_{3}^{-}\right)$in the semi-confined to $1 \mathrm{mg} / \mathrm{l}$ in the unconfined part of the aquifer. Presently, the mean concentration is around $35 \mathrm{mg} / \mathrm{l}$, from $20 \mathrm{mg} / \mathrm{l}$ at the aquifer bottom to more than $175 \mathrm{mg} / \mathrm{l}$ in the contaminated zones from the upper aquifer (Hallet, 1999a).

From 1993 to 1996, an EC Life's project called "Programme Action Hesbaye", involving agricultural engineers and hydrogeologists, was funded in order to estimate and locate nitrate sources and to propose actions to prevent groundwater contamination due to fertilizers applied to arable crops (Dautrebande et al., 1996). Since 1997, awareness campaigns have been conducted and protection measures taken. It is expected that these actions will result in a decrease in nitrate concentrations in the aquifer. Unfortunately, a strong persistence of nitrate contamination is observed, in relation to long transit times in the unsaturated chalk and long residence time in the saturated part of the aquifer. This leads to important delays between undertaken actions and groundwater quality improvement. Due to that, reliable prediction models are needed to evaluate and assess the longterm efficiency of these actions. A good understanding of recharge and migration mechanisms and a good parameterization of key processes are needed.

For studying the saturated zone of the Hesbaye aquifer, more than 30 multi-tracer experiments were carried out. Based on that, transport mechanisms in the aquifer were investigated and conceptualized, while flow and transport parameters in the chalk were estimated (Biver, 1993; Hallet, 1999a). It was also possible to explain and to model nitrate dynamics in soils (i.e., up to $1.5 \mathrm{~m}$ deep) and in the saturated part of the aquifer. However, due to a lack of field experiments, nitrate fluxes across the unsaturated loess formations were estimated using mathematical modelling without actual experimentation in the field. Despite a rough estimation of $1 \mathrm{~m} /$ year for the down-migration of nitrate in the unsaturated loess (Dautrebande et al., 1999), the understanding of groundwater flow and transport phenomena had to be improved, particularly in the dual porosity weathered chalk. The chalk can be considered as a dual porosity-dual permeability material (e.g., Barker and Foster, 1981; Biver, 1993; Price et al., 1993; Younger and Elliot, 1995; Hallet, 1999a; Brouyère, 2001), which is made up of a matrix and fissures. The matrix is characterized by a high porosity and a low hydraulic conductivity at saturation. The porosity associated with the fissures is very low but their contribution to the saturated hydraulic conductivity is predominant. Due to that structure, in the saturated zone, contaminants migrate quickly along fissures; in the same time, they can be strongly retarded by migration in the immobile water located in the matrix. In the unsaturated zone, the saturation degree of the chalk determines if the fissures actually play a role in the mobility and retardation of contaminants. It is influenced by factors such as recharge conditions prevailing at the top of the chalk or the structural characteristics of the chalk. The concomitant effect of these two factors on the mobility of water and contaminants in the unsaturated chalk had to be investigated.

To have a better knowledge and understanding of groundwater recharge mechanisms and transport processes in the unsaturated zone of the Hesbaye aquifer, an experimental study 
was performed in the Hesbaye Region, funded by the Walloon Ministry of Natural Resources and Environment. Seven boreholes were drilled at various depths in the unsaturated zone and in the aquifer. Undisturbed core samples were collected during the drilling of the boreholes for laboratory measurements. In the field, various hydraulic tests and tracer experiments were performed. Most of these measurements are described hereafter. Conclusions are drawn concerning recharge mechanisms, migration and retardation of solutes in the unsaturated zone and hydrodispersive behaviour and vulnerability of the variably saturated chalk. More particularly, a conceptual model is proposed for explaining the hydrodynamic and hydrodispersive behaviour of chalk under variable recharge conditions.

\subsection{Geological and hydrogeological context}

\subsubsection{Regional geology and hydrogeology}

The Hesbaye plateau extends over about $350 \mathrm{~km}^{2}$. Altitudes range from $206 \mathrm{~m}$ in the South-West to $80 \mathrm{~m}$ in the North-East part of the region. The substratum is made of, from top to bottom (Fig. 1):

- quaternary loess of variable thickness, up to $20 \mathrm{~m}$;

- locally, several meters of tertiary sand deposits;

- a maximum of $10 \mathrm{~m}$ of flint conglomerates, which is a heterogeneous material made of dissolved chalk residues (flints, sand, clay and locally phosphate residuals);

- Senonian chalks showing depths ranging from a few meters, up to $70 \mathrm{~m}$, in which the aquifer is located;

- several meters of smectite clay of low hydraulic conductivity, considered as the aquifer basis.

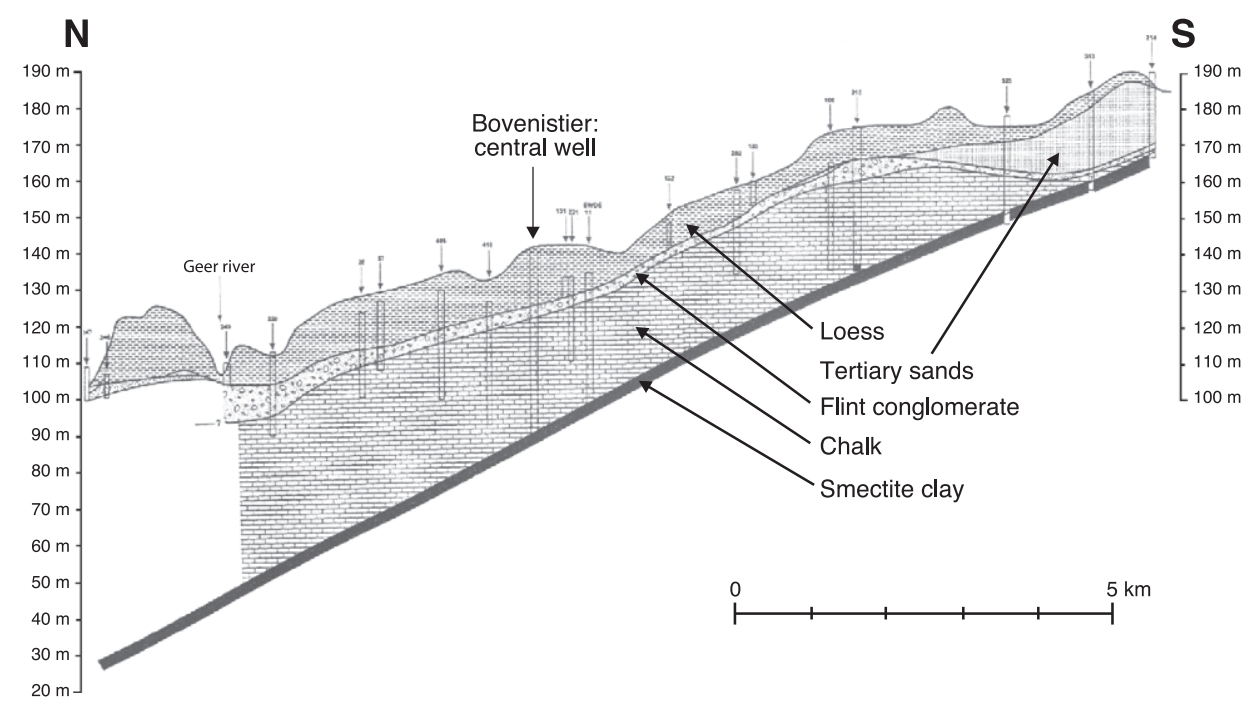

Fig. 1. Geological cross-section in the Hesbaye aquifer. 
The mean hydraulic gradient in the aquifer is North-oriented (Fig. 2), ranging from 0.01 in the South to 0.003 in the North, close to the River Geer, draining most of the groundwater (Dassargues and Monjoie, 1993). Most of the aquifer is unconfined, except in the North, where semi-confined conditions prevail under the Geer alluvial deposits and locally, where confined conditions prevail under tertiary clayey sediments. The aquifer configuration has a high influence on nitrate concentrations and evolutions (Hallet, 1999b). Average nitrate concentrations range from less than $20 \mathrm{mg} / \mathrm{l}$ in the semi-confined, up to 35 to $45 \mathrm{mg} / \mathrm{l}$ in the unconfined part of the aquifer. Vertically, nitrate concentrations decrease in depth at a range of $0.8 \mathrm{mg} / \mathrm{l} / \mathrm{m}$.

\subsubsection{Geological context of the experimental site}

The experimental site is located at Bovenistier (Fig. 2). The location of the different boreholes is given in Fig. 3. A central well (PC) was drilled down to the aquifer bottom $(50 \mathrm{~m})$. An observation well (Pz CS) was drilled and screened in the saturated zone $(34 \mathrm{~m})$. Four subsequent wells were drilled and screened in the unsaturated zone: Pz CNS in the unsaturated chalk (19.2 m), Pz CGL in the flint conglomerate $(15.8 \mathrm{~m})$ and Pz LB (9.4 m) and LS $(5.8 \mathrm{~m})$ in the loess formations. For each borehole, core drilling was first performed to take undisturbed samples. After hole enlargement, the central well (PC) was equipped with $150 \mathrm{~mm}$ PVC screen and casing. It is screened between 28.5 and 48.5 $\mathrm{m}$ below the ground. The other wells were equipped with 113-mm PVC screen and casing. $\mathrm{Pz} \mathrm{CS}$ is screened between 28 and $33 \mathrm{~m}$ below the ground, Pz CNS between 17.2 and 19.2 m, Pz CGL between 13.6 and 14.6 m, Pz LB between 7.4 and $9.4 \mathrm{~m}$ and Pz LS between 3.8 and $5.8 \mathrm{~m}$. In addition, an observation well (Pz 12), drilled previously for the definition

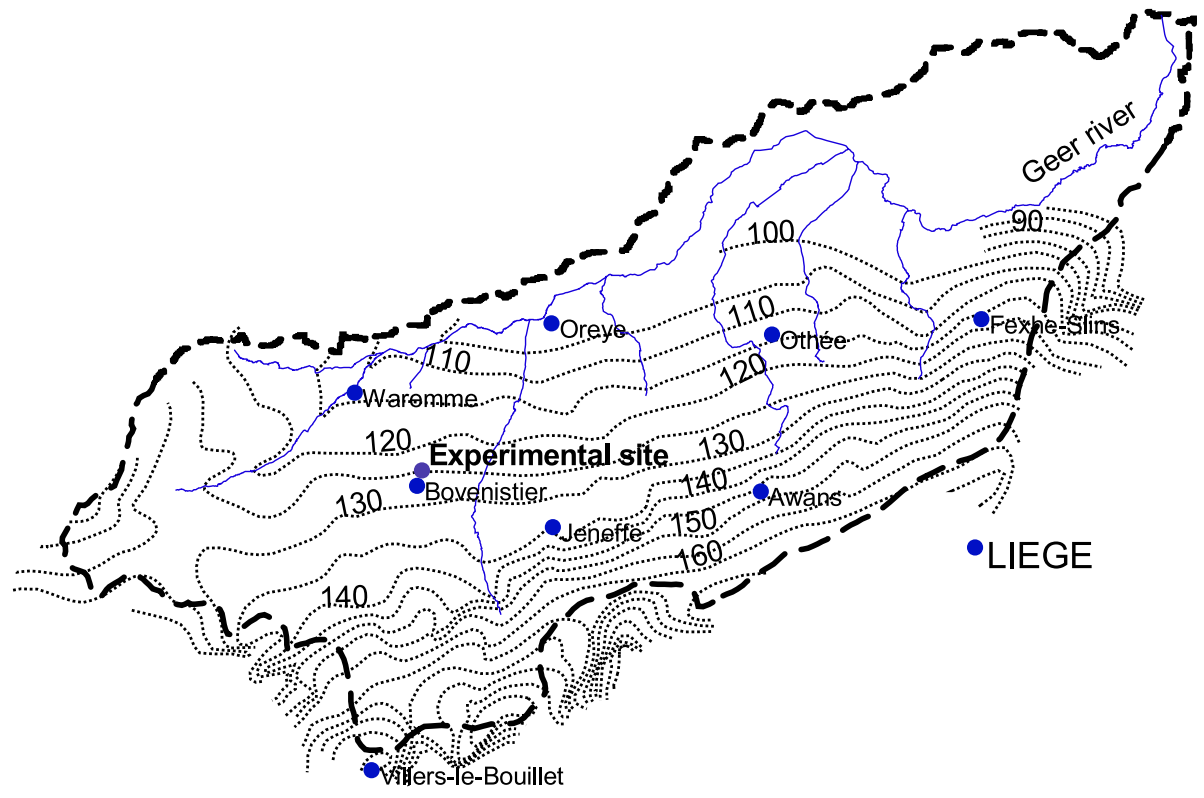

Fig. 2. Piezometric map of the Hesbaye aquifer (September 1984). 

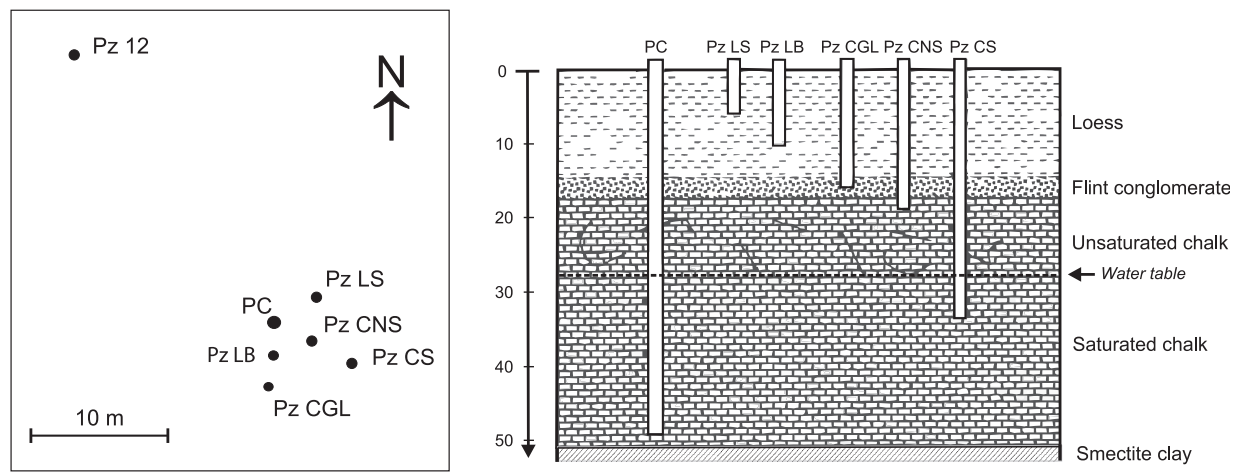

Fig. 3. Localization and depths of the wells.

of protection zones of a neighbouring water catchment area, was available for measurements close to the experimental site. This well is screened between 24.3 and $49 \mathrm{~m}$ below the ground.

\section{Laboratory experiments}

Undisturbed core samples were collected at different depths, mostly in the central well but also in the other wells. These samples were sealed into containers and sent the same day to the laboratory.

\subsection{Hydraulic conductivity measurements performed on core samples}

Measurements of the saturated hydraulic conductivity were performed on undisturbed samples in a triaxial cell. Samples of $10-\mathrm{cm}$ diameter and $10-\mathrm{cm}$ length were placed in a double casing made up of thermo-retractable and viton layers, both ends being protected by a filter paper. They were exposed to a hydrostatic pressure of $0.4 \mathrm{MPa}$, between two porous plates in a triaxial cell. Water was injected at the bottom of the sample at a pressure of $0.2 \mathrm{MPa}$ above atmosphere, producing a hydraulic gradient of about 200 . The quantity of water flowing out from the upper part of the sample was monitored with time. The calculation of the hydraulic conductivity is based on Darcy's law, when steady state flow conditions across the sample were reached.

Table 1 summarizes the results of measurements performed on 17 samples, mostly collected in the loess formations. Hydraulic conductivity values range from $1.3 \times 10^{-10}$ to $3.1 \times 10^{-8} \mathrm{~m} / \mathrm{s}$ for the loess formations and from $7.8 \times 10^{-9}$ to $1.8 \times 10^{-8} \mathrm{~m} / \mathrm{s}$ for the conglomerate. The hydraulic conductivity of the chalk was estimated to $1.3 \times 10^{-8} \mathrm{~m} / \mathrm{s}$ based on a single measurement. For the loess, the high pressure applied in the cell probably led to the compaction of tested samples, leading to an underestimation of hydraulic conductivity compared to actual field values. The flint conglomerate being a dissolution residue of the chalk, mixed with material coming from surrounding layers, it is characterized by a strong heterogeneity, including the presence of centimetric to decimetric 
Table 1

Synthesis of laboratory measurements of hydraulic conductivity performed on undisturbed core samples

\begin{tabular}{lllll}
\hline Borehole & Depth $(\mathrm{m})$ & Material & Density $\left(\mathrm{g} / \mathrm{cm}^{3}\right)$ & $\begin{array}{l}\text { Hydraulic } \\
\text { conductivity }(\mathrm{m} / \mathrm{s})\end{array}$ \\
\hline Central well & 2 & Loess & 1.95 & $5.3 \times 10^{-10}$ \\
& 6 & Loess & 2.09 & $3.1 \times 10^{-8}$ \\
& 8 & Loess & 2.01 & $6.7 \times 10^{-10}$ \\
& 12 & Loess & 2.01 & $7.8 \times 10^{-9}$ \\
& 17.9 & Conglomerate & 2.07 & $1.8 \times 10^{-8}$ \\
Pz CS & 18 & Conglomerate & 2.02 & $7.8 \times 10^{-9}$ \\
Pz CNS & 7.25 & Loess & 2.14 & $5.3 \times 10^{-9}$ \\
& 1 & Loess & 2.10 & $2.0 \times 10^{-10}$ \\
& 4 & Loess & 2.06 & $2.1 \times 10^{-9}$ \\
& 6 & Loess & 2.16 & $2.3 \times 10^{-9}$ \\
Pz CGL & 7.5 & Loess & 2.01 & $4.3 \times 10^{-9}$ \\
Pz LS & 9.5 & Loess & 2.15 & $1.0 \times 10^{-9}$ \\
& 12.75 & Loess & 2.11 & $5.3 \times 10^{-9}$ \\
& 17 & Chalk & 1.73 & $1.3 \times 10^{-8}$ \\
& 7.5 & Loess & 2.13 & $7.6 \times 10^{-9}$ \\
& 2 & Loess & 2.04 & $6.0 \times 10^{-10}$ \\
\end{tabular}

flint blocks. It is unlikely that the samples are representative of in situ material. The chalk sample being too small to integrate the fissured component, it is representative of the rock matrix only.

\subsection{Physical properties of unsaturated formations}

Textural properties and bulk density were measured on loess samples, while retention curves were determined on both loess and chalk samples.

\subsubsection{Texture and density}

Using bulk density measurements determined by weighing vacuumed samples of 100 $\mathrm{cm}^{3}$ and considering matrix densities of 2.65 and $2.7 \mathrm{~g} / \mathrm{cm}^{3}$ for the loess and the chalk, respectively, an estimation of the sample total porosity can be assessed.

The evolution with depth of bulk density and total porosity are presented in Fig. 4. Bulk density values range between 1.46 and $1.68 \mathrm{~g} / \mathrm{cm}^{3}$ (mean: 1.57) for the loess formation and between 1.33 and $1.68 \mathrm{~g} / \mathrm{cm}^{3}$ (mean: 1.51) for the chalk. Corresponding values of total porosity range between 0.37 and 0.45 (mean: 0.41 ) for the loess and between 0.38 and 0.51 (mean: 0.44) for the chalk. Measured density and porosity values for the loess formation are typical and representative of the Hesbaye Region (Dautrebande et al., 1996). For the chalk, values are representative of rock matrix properties.

Textural analyses performed on loess samples provided particle-size distribution curves, further re-grouped into the three main classes used in the Belgian textural triangle: (a) the clay fraction, corresponding to particle diameters less than $2 \mu \mathrm{m}$, (b) the silt fraction corresponding to particle diameters ranging between 2 and $50 \mu \mathrm{m}$ and (c) the sand fraction corresponding to particle diameters ranging between 50 and $2 \mathrm{~mm}$. The 

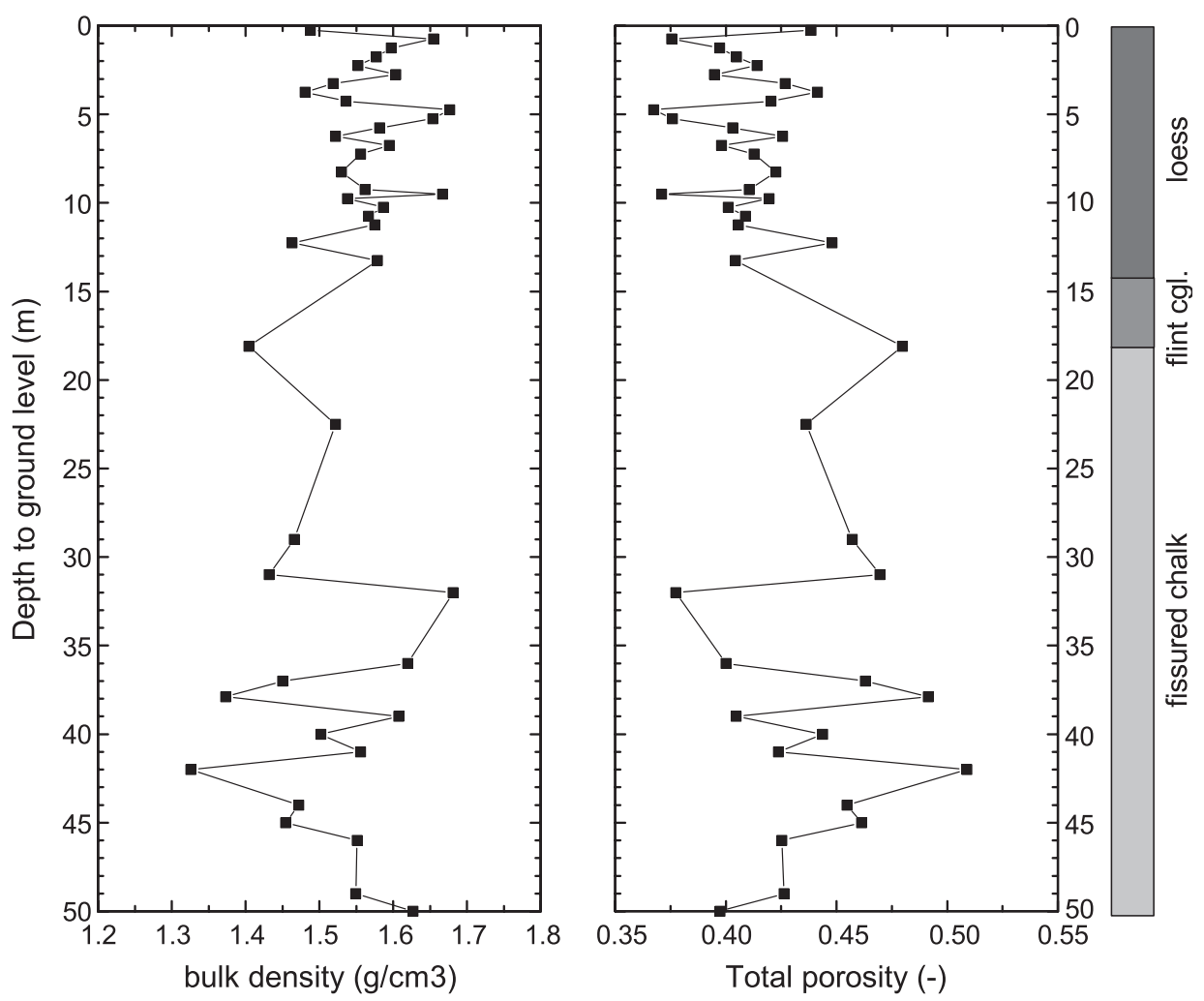

Fig. 4. Variation with depth of bulk density and total porosity measured on core samples.

evolution with depth of these three classes is presented in Fig. 5. The clay and sand contents, respectively, range between $11 \%$ and $34 \%$ and between $1 \%$ and $19 \%$. Mean values are $21 \%$ for the clay content, $71 \%$ for the silt content and $8 \%$ for the sand content. According to the Belgian nomenclature, these deposits may be classified as loess to heavy loess materials.

\subsubsection{Retention curves}

The retention curve relates the water content in the unsaturated formation to the applied suction head. From 20-cm-long undisturbed samples collected during the borehole drilling, two cylindrical samples of $100 \mathrm{~cm}^{3}$ were taken for measurement of the retention curve. The samples were first saturated with water, then submitted to increasing suctions in a Richards apparatus (applied suctions ranging between 0.10 and $150 \mathrm{~m}$ ). Respectively, 43 and 23 retention curves were measured on loess and chalk samples.

Retention curves measured on chalk samples are representative of the unsaturated behaviour of the chalk matrix only. However, most retention curves measured on chalk samples showed a relatively rapid desaturation between full saturation and an applied suction of $0.4 \mathrm{~m}$. This may be attributed to the desaturation of micro-fissures in the chalk 


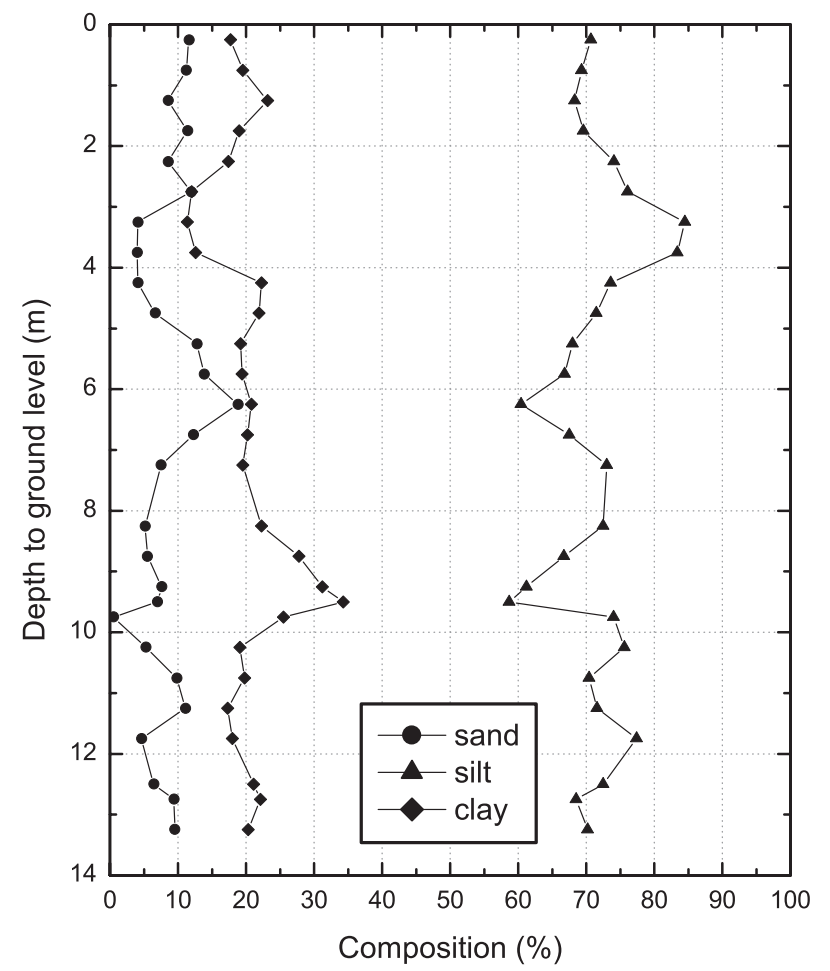

Fig. 5. Variation with depth of loess texture.

matrix. When these micro-fissures are drained, high suctions have to be applied in order to observe a significant variation of water content in the matrix. This reflects the importance of the micro-porosity of the chalk where water is almost immobile. The hydrodynamic behaviour of the variably saturated chalk, as well as the consequences on hydrodispersive properties will be discussed further.

Using the model of van Genuchten (1980), theoretical retention curves were fitted on the experimental ones, providing an estimation of the van Genuchten parameters for each tested sample (Brouyère, 2001). This model considers four parameters: the saturated water content $\theta_{\mathrm{s}}(-)$, the residual water content $\theta_{\mathrm{r}}(-)$, the inverse of air entry pressure $\alpha\left(\mathrm{m}^{-1}\right)$ and a pore distribution factor $n(-)$. Fig. 6 allows comparison of water contents measured at different suctions on the loess and chalk samples and water contents calculated using the van Genuchten relationships. For the chalk, in order to get parameters representative of the matrix, adjustments were performed considering only water contents measured at suctions equal or higher than $0.4 \mathrm{~m}$. In order to reduce the number of fitting parameters, the residual water content was arbitrarily set to 0.01 , following the recommendation of Wösten (1997). Due to the relatively wet climate prevailing in the Hesbaye region, strong desaturation of soils does not occur and accuracy in the dry range of the retention curves is not needed. Table 2 summarizes the mean values of adjusted parameters for the loess and the chalk, respectively. 


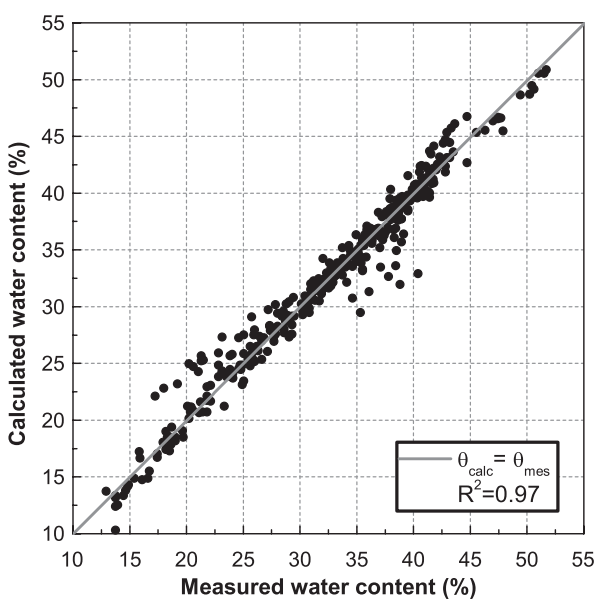

(a) loess

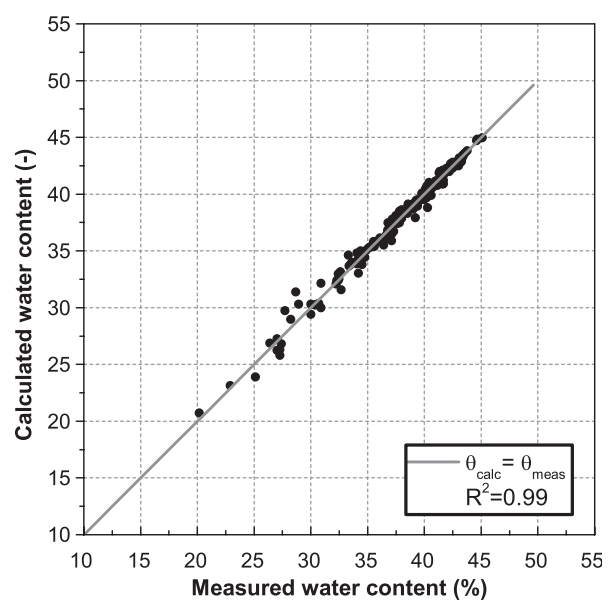

(b) chalk matrix

Fig. 6. Measured water contents on (a) the loess, (b) the chalk matrix samples and water contents estimated using van Genuchten relationships.

Using both physical properties and retention curves measured on the loess samples, Brouyère (2001) tried to derive pedotransfer functions for the loess formations characteristic of the Hesbaye region. The results (not shown) are particularly useful for the establishment, at a relatively low cost, of unsaturated properties of loose formations, for large-scale applications (van Genuchten and Leij, 1992, Mohanty and van Genuchten, 1996).

\subsection{Nitrate and pesticides concentrations in core samples}

Core samples collected every $0.5 \mathrm{~m}$ during the drilling of the boreholes were analyzed for their concentrations in nitrate and lenacil pesticide (commercial name: venzar). This pesticide was considered because it was used almost every year on the experimental site plot. Nitrate was analyzed using the Guiot method (Guiot et al., 1992). Details about the analysis of lenacil in soil samples can be found in Monjoie et al. (2000).

For nitrate, results are presented in Fig. 7. Concentrations (expressed as $\mathrm{NO}_{3}^{-}$) range from 10 to $217 \mathrm{mg} / \mathrm{l}$, with a relatively high variability between wells. The evolution of mean concentration with depth shows peaks around $1 \mathrm{~m}(92 \mathrm{mg} / \mathrm{l}), 3.5 \mathrm{~m}$ $(140 \mathrm{mg} / \mathrm{l}), 6.5 \mathrm{~m}(75 \mathrm{mg} / \mathrm{l})$ and $13.5 \mathrm{~m}(49 \mathrm{mg} / \mathrm{l})$ at the bottom of the loess layer.

Table 2

Mean values of van Genuchten parameters for the retention curves measured on the loess samples

\begin{tabular}{llll}
\hline Material & $\theta_{\mathrm{s}}(\%)$ & $\alpha\left(\mathrm{m}^{-1}\right)$ & $n(-)$ \\
\hline Loess & 44.49 & 7.57 & 1.16 \\
Chalk matrix & 41 & $9.9 \times 10^{-2}$ & 1.1 \\
\hline
\end{tabular}




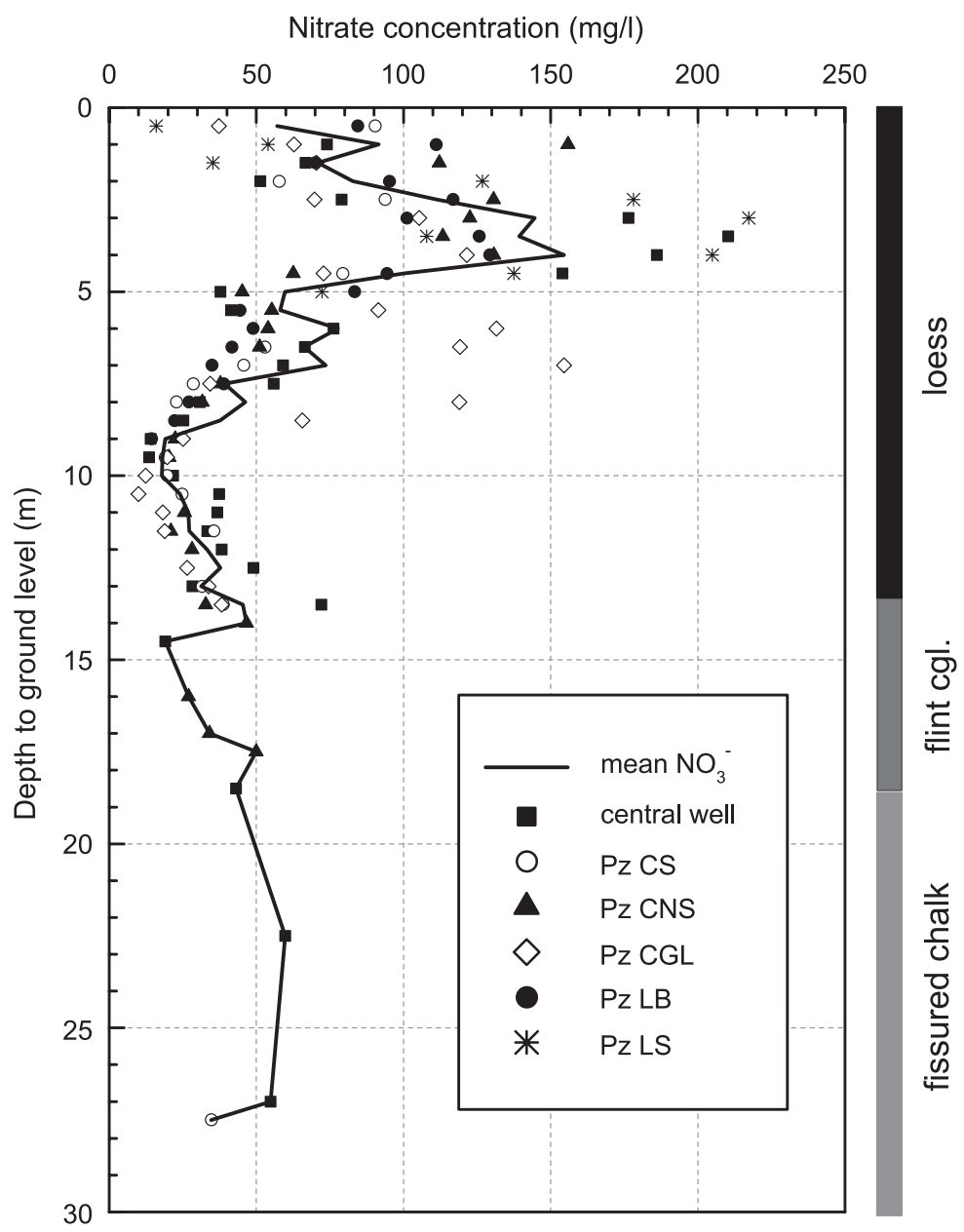

Fig. 7. Variation with depth of nitrate concentration in samples collected during the drilling of the boreholes.

The lower concentrations are observed at a depth of $9.5 \mathrm{~m}(18 \mathrm{mg} / \mathrm{l})$. Dautrebande et al. (1999) correlated the 3.5- and 6.5-m peaks with spinach and bean grown in the plot in 1995 and 1992, respectively. This may indicate a nitrate down migration of $1 \mathrm{~m} /$ year.

For the lenacil pesticide, all measured values were lower than the detection limit $(5 \mu \mathrm{g} /$ $\mathrm{kg}$ in soil samples), except the first soil sample, taken at a depth of $0.5 \mathrm{~m}$, where the concentration is closed to the detection limit. The detection limit was probably too high to identify clearly the presence of the pesticide in the samples; however, such low concentrations can also be explained by the degradation or by the fixation of this product in the first soil horizons. In a pesticide properties database, USDA (1999) mentions a halflife of around 80 days and relatively high sorption capacities in loamy soils (http://www. arsusda.gov/acsl/textfiles/LENACIL.htm). 


\section{In situ experiments}

\subsection{Down-hole geophysics}

In each drilled borehole, gamma-ray, gamma-gamma and neutron logging were performed, providing continuous profiles of several physical properties of geological formations. Basic principles governing these methods can be found in Repsold (1989). As an illustration, geophysical logs measured in the central well are presented in Fig. 8. The most significant observations and conclusions are summarized hereafter.

Loess formations ( 0 to $14 \mathrm{~m}$ ) show a high and variable radioactivity, around 75 to 100 counts per seconds (cps). The density of the material is relatively high. Neutron logging reveals that the water content is variable, probably relating to rainy episodes.

In the conglomerate formation (14 to $18 \mathrm{~m}$ ), the low radioactivity can be associated with the low clay content. The neutron logs also show that water contents are low. These observations lead to the conclusion that this layer has a relatively high sandy content, with good drainage capacity.

The chalk formation is characterized by a low radioactivity, less than $25 \mathrm{cps}$. However, values as high as $100 \mathrm{cps}$ are encountered at the top of the chalk. This may be attributed to an accumulation of residual clay coming from rock alteration or to phosphate mineralization at the base of the conglomerate level. The gamma-gamma logging reveals that the chalk is characterized by a low density between 20 and $28 \mathrm{~m}$, probably in relation with progressive alteration and dissolution, due to periodic water table fluctuations. During drilling operations, it proved impossible to recover any rock core at similar depth because the material was completely disaggregated.

The position of the water table is clearly identified by the important increase of water content and density. The capillary fringe is highlighted when comparing the short distance (SSN) and the long distance (LSN) neutron logs. The former investigates only a short distance around the well; it is influenced by water present in the well bore. The latter investigates more important distances into the formation; it is influenced both by water in the well bore and by the capillary fringe at some distance from the borehole. The cps decrease observed on the LSN log in the saturated zone relates to the fact that all neutrons are strongly slowed down and captured during migration from the emitter to the receptor. At a depth of $24 \mathrm{~m}$, a level of very low density is observed on each log. Below this level, neutron logs systematically reveal higher water contents. This indicates an unconsolidated level which seems to limit locally the capillary rise in the chalk.

\subsection{Pumping tests performed in the saturated zone}

\subsubsection{Pumping tests configuration}

In order to assess hydrodynamic properties prevailing in the test site and to optimize experimental conditions for performing tracer experiments (optimization of pumping rate, etc.), long duration pumping tests were performed in each well screened in the saturated zone. During these experiments, the water table was approximately at a depth of $28 \mathrm{~m}$. In addition, a step drawdown test was performed at the central well. Results were interpreted using well-known methods such as the Dupuit solution for steady-state conditions and the 


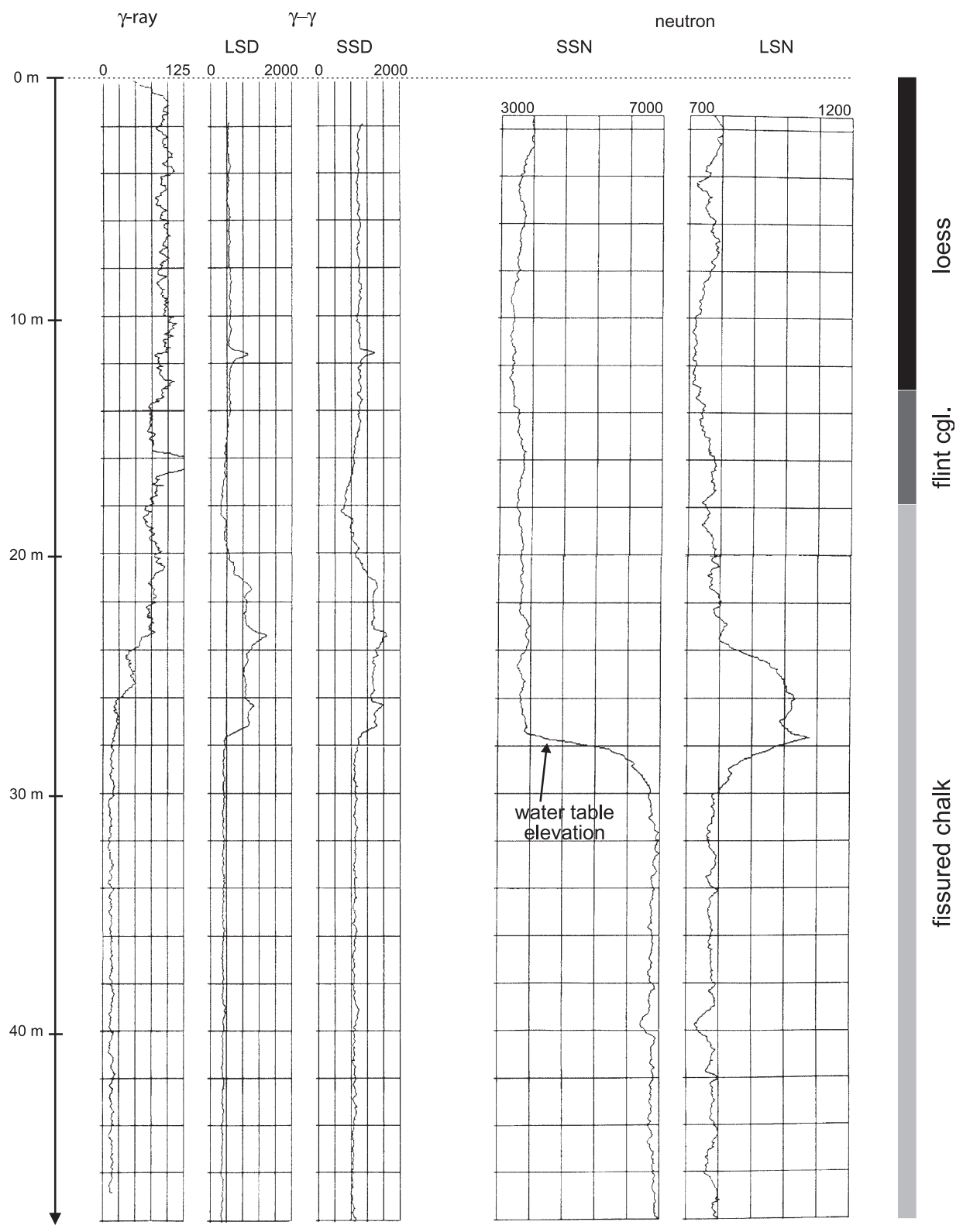

Fig. 8. Geophysical logs measured at the well Pz CS.

Theis solution for transient state conditions. In the latter case, the hydraulic conductivity $\left(\mathrm{L} \mathrm{T}^{-1}\right)$ was estimated by dividing the transmissivity $\left(\mathrm{L}^{2} \mathrm{~T}^{-1}\right)$ by the saturated thickness (L) of the aquifer. Table 3 summarizes pumping test configurations and results. When multiple values are listed in a same cell, they correspond to interpretations based on 
Table 3

Estimated hydraulic conductivity values drawn from pumping tests performed in the experimental site

\begin{tabular}{|c|c|c|c|c|c|c|c|c|}
\hline \multirow{3}{*}{$\begin{array}{l}\text { Pumping } \\
\text { well }\end{array}$} & \multirow{3}{*}{$\begin{array}{l}\text { Pumping } \\
\text { rate }\left(\mathrm{m}^{3} / \mathrm{h}\right)\end{array}$} & \multirow{3}{*}{$\begin{array}{l}\text { Interpretation } \\
\text { method }\end{array}$} & \multicolumn{6}{|c|}{ Chalk hydraulic conductivity estimated at the observation wells $(\mathrm{m} / \mathrm{s})$} \\
\hline & & & \multicolumn{2}{|l|}{$\mathrm{Pz} 12$} & \multicolumn{2}{|l|}{$\mathrm{Pz} \mathrm{CS}$} & \multicolumn{2}{|l|}{$\mathrm{PC}$} \\
\hline & & & Drawdown & Recovery & Drawdown & Recovery & Drawdown & Recovery \\
\hline \multirow[t]{3}{*}{$\mathrm{Pz} 12$} & 15.59 & Theis & $\begin{array}{l}4.4 \times 10^{-5} \\
8.8 \times 10^{-5} \\
7.3 \times 10^{-5}\end{array}$ & $1.46 \times 10^{-4}$ & - & - & - & - \\
\hline & 8.1 & Dupuit & $7.5 \times 10^{-5}$ & - & - & - & - & - \\
\hline & & Theis & $1.26 \times 10^{-4}$ & $3.15 \times 10^{-4}$ & - & $\begin{array}{l}1.26 \times 10^{-5} \\
3.94 \times 10^{-4} \\
1.26 \times 10^{-4}\end{array}$ & - & $\begin{array}{l}7.12 \times 10^{-4} \\
3.78 \times 10^{-3}\end{array}$ \\
\hline $\mathrm{Pz} \mathrm{CS}$ & 4.07 & $\begin{array}{l}\text { Dupuit } \\
\text { Theis }\end{array}$ & $\begin{array}{c}- \\
3.6 \times 10^{-3} \\
9.22 \times 10^{-4} \\
1.59 \times 10^{-3}\end{array}$ & $\begin{array}{c}- \\
2.84 \times 10^{-3} \\
1.11 \times 10^{-3}\end{array}$ & $\begin{array}{c}7.05 \times 10^{-5} \\
2.8 \times 10^{-6} \\
9.0 \times 10^{-5}\end{array}$ & $\begin{array}{c}- \\
2.52 \times 10^{-4}\end{array}$ & $\begin{array}{c}- \\
3.42 \times 10^{-3} \\
1.37 \times 10^{-3}\end{array}$ & $\begin{array}{c}- \\
1.39 \times 10^{-3}\end{array}$ \\
\hline \multirow[t]{6}{*}{$\mathrm{PC}$} & 1.77 & Dupuit & $5.6 \times 10^{-5}$ & - & - & - & - & - \\
\hline & $\begin{array}{l}4.05 \\
5.48\end{array}$ & $\begin{array}{l}\text { Dupuit } \\
\text { Dupuit }\end{array}$ & $\begin{array}{l}8.9 \times 10^{-5} \\
3.3 \times 10^{-5}\end{array}$ & - & - & - & - & - \\
\hline & $\begin{array}{l}5.40 \\
6.55\end{array}$ & Dupuit & $\begin{array}{l}3.3 \times 10 \\
1.9 \times 10^{-5}\end{array}$ & - & - & - & - & - \\
\hline & 6.68 & Dupuit & $1.7 \times 10^{-5}$ & - & - & - & - & - \\
\hline & 6.6 & Dupuit & $\begin{array}{r}7.0 \times 10^{-4} \\
3.29 \times 10^{-4}\end{array}$ & - & - & - & $1.7 \times 10^{-5}$ & - \\
\hline & & Theis & & $\begin{array}{l}2.1 \times 10^{-4} \\
7.8 \times 10^{-5}\end{array}$ & $\begin{array}{c}1.96 \times 10^{-4} \\
9.4 \times 10^{-5}\end{array}$ & $\begin{array}{l}2.1 \times 10^{-4} \\
7.8 \times 10^{-5}\end{array}$ & $\begin{array}{l}6.0 \times 10^{-6} \\
1.4 \times 10^{-5} \\
3.3 \times 10^{-5}\end{array}$ & $\begin{array}{r}4.63 \times 10^{-4} \\
1.2 \times 10^{-5} \\
3.0 \times 10^{-6}\end{array}$ \\
\hline
\end{tabular}


different parts of the drawdown or recovery curves. This may reflect variations in hydraulic conductivity vertically or laterally.

\subsubsection{Initial conclusions drawn from the pumping tests}

Estimated hydraulic conductivity values show an important variability that reveals the heterogeneity affecting the fissured chalk aquifer. Highest values are encountered at $\mathrm{Pz}$ $\mathrm{CS}$, screened in the upper part of the saturated zone. Lowest values are encountered at the central well. These observations are in good agreement with other pumping tests performed in the Hesbaye aquifer, where highest hydraulic conductivity values are usually observed in the upper part of the chalk layer (Hallet, 1999a). This fact may be explained by strain relaxation and weathering of the upper chalk layer compared to the deep chalk. Horizontally, results indicate higher hydraulic conductivity values close to $\mathrm{Pz} 12$.

Hydraulic conductivity values calculated at each pumping well are generally higher during the recovery phase than during the pumping phase, indicative of head losses or progressive dewatering of fractures, which can also explain the lower transmissivity values estimated when boreholes are used as pumping wells rather than observation wells.

\subsection{Infiltration tests performed in the unsaturated zone}

Infiltration tests were performed in the four wells drilled in the unsaturated zone, in order to estimate hydraulic conductivities of the loess, the conglomerate and the chalk. In the unsaturated zone, classical interpretation methods remain applicable assuming that the formation around the injection point becomes quickly saturated with water and remains saturated for the whole experiment (Allen and Price, 1990). Constant head and falling head injection tests were performed. Several interpretation techniques can be found in the literature (e.g., Hvorslev, 1951; Stephens and Neuman, 1982). Here, the "LefrancBrillant" interpretation formulae were considered. Details can be found in Mabillot (1989). Fig. 9 shows measured water drawdown with time and the corresponding interpretation diagram for the falling head tests.

Estimated hydraulic conductivities are summarized in Table 4. Values estimated from falling head tests are a factor 2 to 10 higher than values estimated from constant head tests. Two reasons may be found: (a) falling head tests were generally performed after constant head tests, inducing higher water saturation conditions close to the injection point, increasing locally the hydraulic conductivity; (b) the quantity of water injected during the falling head test being far lower than for the constant head test, it is likely to enter quickly in the medium by capillary suction, accelerating the water level falling in the tested well.

Lowest hydraulic conductivity values are encountered in the loess formation, where results indicate a possible decrease of hydraulic conductivity with depth, probably related to material compaction. In the chalk, the estimated hydraulic conductivity values are somewhat smaller than expected for such a weathered material. However, estimated values are of the same order of magnitude as hydraulic conductivities estimated with pumping tests performed in the saturated zone. Furthermore, infiltration tests provide relatively local results. Due the high heterogeneity of the chalk, it can be assumed that the actual saturated hydraulic conductivity is underestimated. 

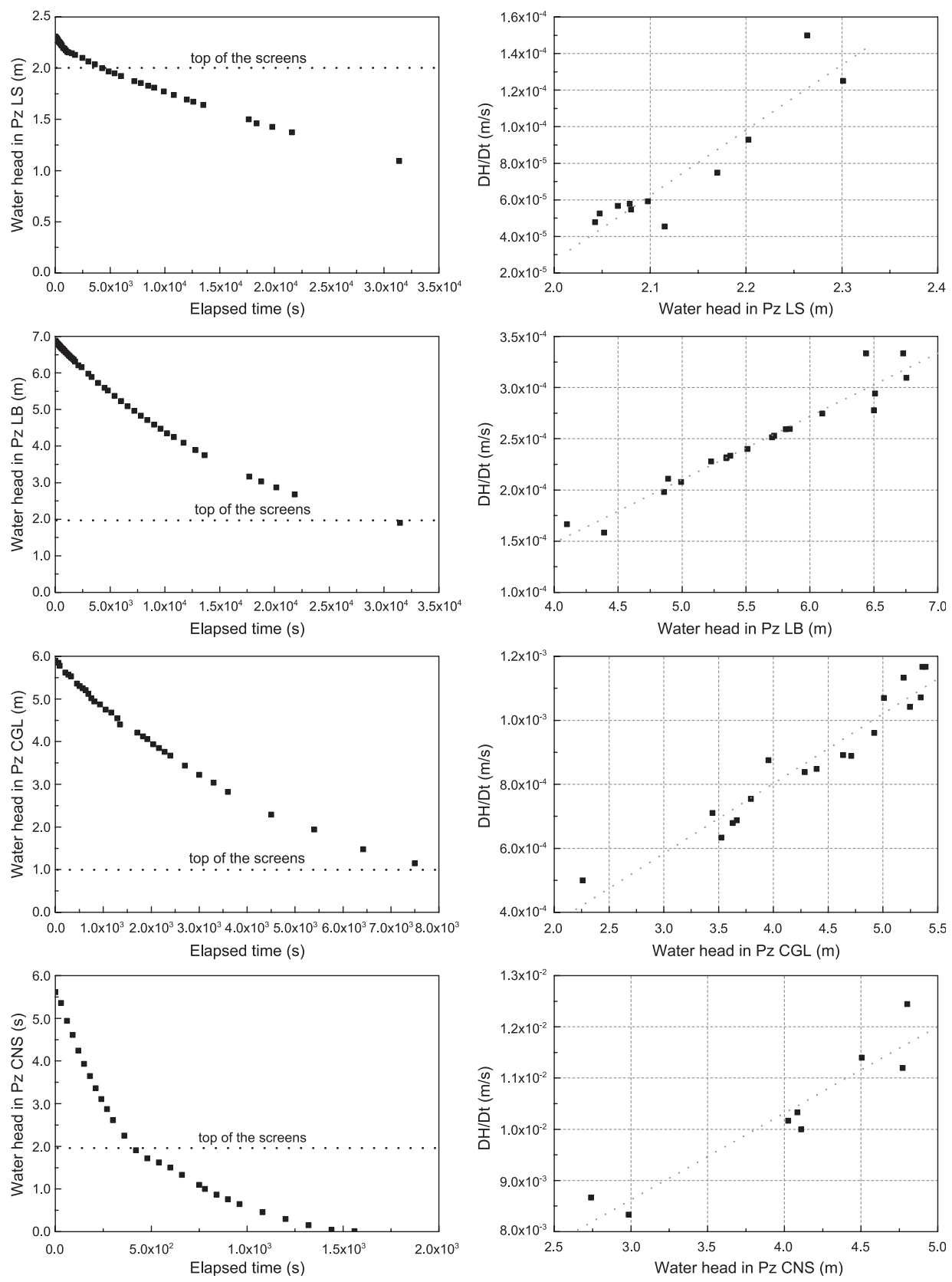

Fig. 9. Results and interpretation of infiltration tests performed in the unsaturated zone (interpretation performed based only on water level measurements above the top the screens). 
Table 4

Estimated hydraulic conductivity values drawn from the interpretation of infiltration tests performed in the unsaturated zone

\begin{tabular}{|c|c|c|c|c|c|}
\hline \multirow[t]{2}{*}{ Well } & \multirow[t]{2}{*}{ Material } & \multicolumn{3}{|c|}{ Constant head test } & \multirow{2}{*}{$\begin{array}{l}\text { Falling head test } \\
K_{\mathrm{s}}(\mathrm{m} / \mathrm{s})\end{array}$} \\
\hline & & $Q\left(\mathrm{~m}^{3} / \mathrm{s}\right)$ & $H_{\text {stab }}(\mathrm{m})$ & $K_{\mathrm{s}}(\mathrm{m} / \mathrm{s})$ & \\
\hline $\mathrm{Pz} \mathrm{LS}$ & Loess & $1.80 \times 10^{-6}$ & 2.31 & $1.70 \times 10^{-7}$ & $2.34 \times 10^{-6}$ \\
\hline Pz LB & Loess & $3.33 \times 10^{-6}$ & 6.89 & $1.04 \times 10^{-7}$ & $3.94 \times 10^{-7}$ \\
\hline \multirow[t]{3}{*}{ Pz CGL } & Flint conglomerate & $11.67 \times 10^{-6}$ & 6.17 & $6.05 \times 10^{-7}$ & $1.95 \times 10^{-6}$ \\
\hline & & $16.70 \times 10^{-6}$ & 7.87 & $6.79 \times 10^{-7}$ & \\
\hline & & $25.00 \times 10^{-6}$ & 9.75 & $8.21 \times 10^{-7}$ & \\
\hline \multirow[t]{2}{*}{$\mathrm{Pz}$ CNS } & Chalk & $66.67 \times 10^{-6}$ & 2.11 & $6.80 \times 10^{-6}$ & $1.66 \times 10^{-5}$ \\
\hline & & $142.83 \times 10^{-6}$ & 5.61 & $5.48 \times 10^{-6}$ & \\
\hline
\end{tabular}

\subsection{Tracer injections performed in the saturated zone}

The main objectives of the tracer experiments in the saturated zone were to estimate tracer velocities and to quantify hydrodispersive properties around the pumping well. Table 5 summarizes information relative to these tracer injections.

\subsubsection{Description of the injections}

Two tracer tests were performed, under radially converging flow conditions, between Pz CS and the central well (tracing distance: $6 \mathrm{~m}$ ). First, an injection of eosin yellowish was performed. For this experiment, a pumping rate of $1.2 \mathrm{~m}^{3} / \mathrm{h}$ was maintained at the central well used to recover the tracers. A second injection was performed using naphtionate. For this injection, a pumping rate of $6.0 \mathrm{~m}^{3} / \mathrm{h}$ was maintained at the central well. Eosin and naphtionate are often considered as conservative tracers (Käss, 1998). During field tracer experiments performed in an alluvial aquifer, Brouyère (2001)

Table 5

Synthesis of data and results of the tracer tests performed in the saturated zone

\begin{tabular}{lll}
\hline & Phase 1 & Phase 2 \\
\hline Tracer & eosin Y & naphtionate \\
Time of injection & $2 / 7 / 1998,14: 50$ & $4 / 7 / 1998,9: 40$ \\
Pumping rate $\left(\mathrm{m}^{3} / \mathrm{h}\right)$ & 1.2 & 6.0 \\
Injected mass $(\mathrm{kg})$ & 0.0053 & 0.0051 \\
Tracer volume $\left(\mathrm{m}^{3}\right)$ & 0.010 & 0.010 \\
Tracer injection duration $(\mathrm{h})$ & $0.031(1.53 \mathrm{~min})$ & $0.036(2.11 \mathrm{~min})$ \\
Water flush volume $\left(\mathrm{m}^{3}\right)$ & 0.127 & 0.132 \\
Water flush duration $(\mathrm{h})$ & $0.29(17.20 \mathrm{~min})$ & $0.22(12.56 \mathrm{~min})$ \\
Time of 1 st arrival & $2 / 7 / 1998,15: 25$ & $4 / 7 / 1998,9: 55$ \\
Minimum transit time $(\mathrm{h})$ & $0.58(35 \mathrm{~min})$ & $0.25(15 \mathrm{~min})$ \\
Maximum velocity $(\mathrm{m} / \mathrm{h})$ & 10.2 & 24 \\
Time of modal restitution & $2 / 7 / 1998,16: 15$ & $4 / 7 / 1998,10: 15$ \\
Modal transit time $(\mathrm{h})$ & $1.42(85 \mathrm{~min})$ & $0.5(30 \mathrm{~min})$ \\
Modal velocity $(\mathrm{m} / \mathrm{h})$ & 4.2 & 1.2 \\
$C^{*}=C_{\text {mod }} / C_{\text {inj }}(-)$ & $1.93 \times 10^{-3}$ & $3.44 \times 10^{-3}$ \\
Recovery factor $(\%)$ & $35($ after $40 \mathrm{~h})$ & $87(\mathrm{after} 77 \mathrm{~h})$ \\
\hline
\end{tabular}


observed that both tracers were not affected by any retardation process. However, naphtionate was affected by degradation during its migration in the alluvial aquifer. Here, because the distance is short, the residence time of the tracer in the aquifer is short. Thus, if degradation occurs, it can be neglected. Fig. 10 presents the measured breakthrough curves

(a)

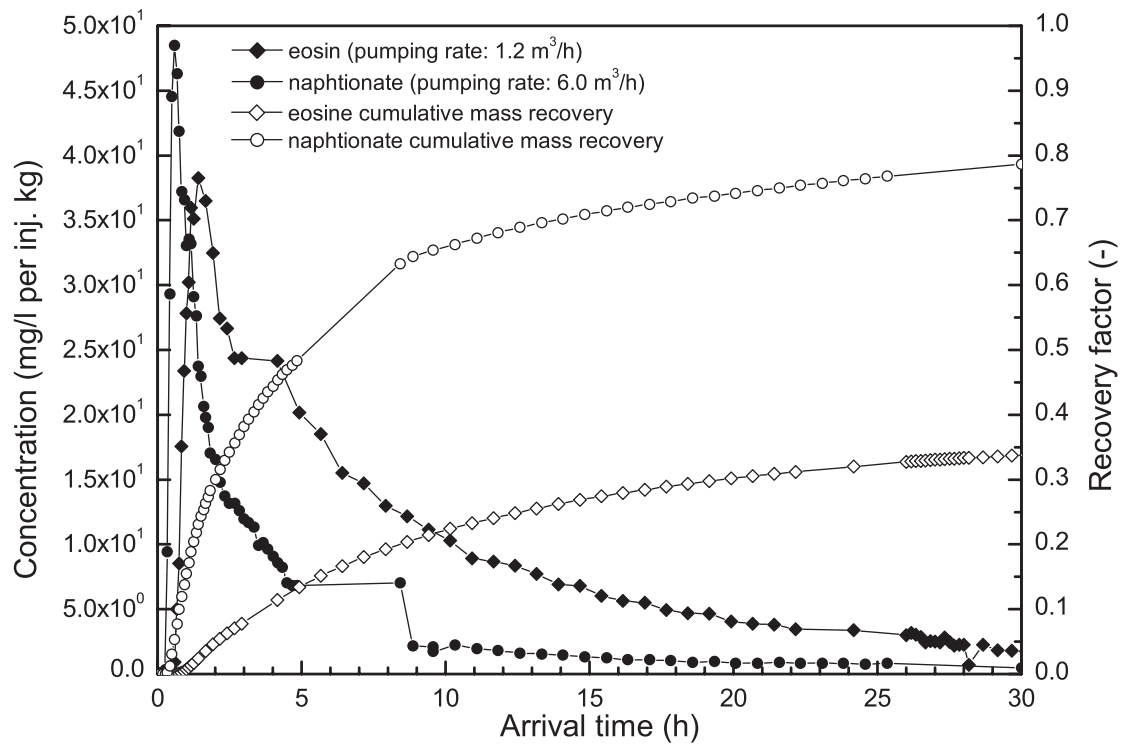

(b)

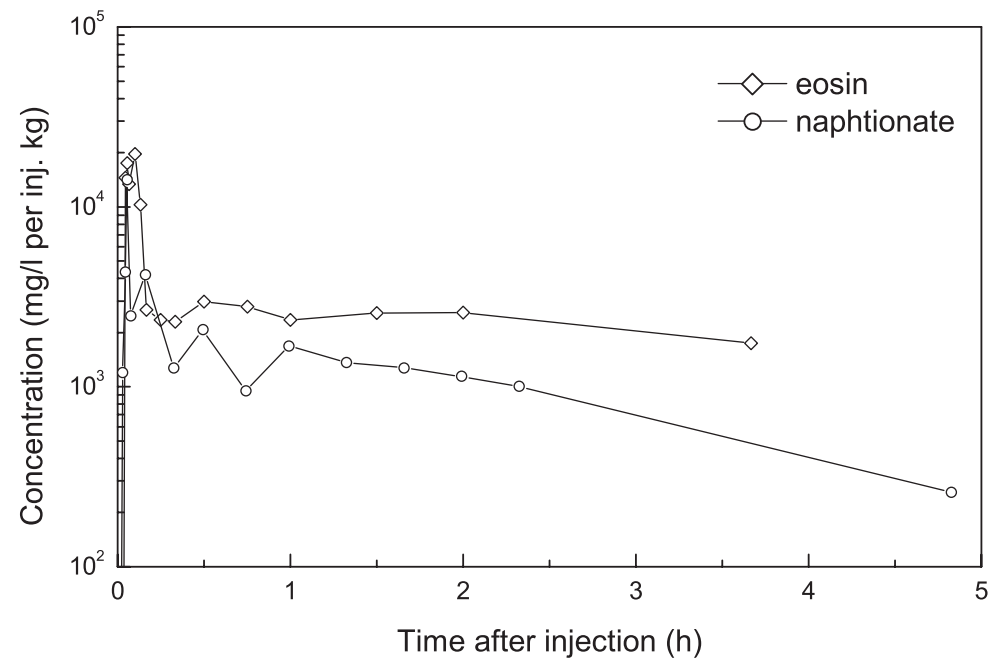

Fig. 10. (a) Breakthrough curves and mass recovery curves of tracers injected in $\mathrm{Pz} \mathrm{CS}$, (b) evolution of concentration at the injection point (Pz CS). 
at the central well, together with tracer concentration evolutions in the injection well. Controlling injection conditions is essential to guaranty that the interpretation is not biased by tracer capturing in the injection well (Brouyère, 2001).

\subsubsection{Discussion of tracer experiments performed in the saturated zone}

Breakthrough curves highlight the very fast transit of tracers in the saturated zone, mostly along fissures. They are characterized by strong asymmetry and tail, reflecting tracer dispersion and retardation in the immobile water located in the chalk matrix. For similar observation times, the first tracer experiment shows a recovery factor (around 40\%) lower than the second tracer experiment (around 90\%). In fact, during the second tracer experiment, the pumping rate is higher, the capture zone of the recovery well is more extended and flow velocities are higher. This limits the tracer mass loss by migration in other directions (i.e., downstream, following the regional groundwater flow) or by diffusion into the immobile water. Furthermore, as highlighted by the concentration monitoring at the injection point, during the first tracer experiment, a more important quantity of tracer remained captured in the injection well, contributing to an apparent lower recovery factor. Hence, considering a water column of $6.1 \mathrm{~m}$ in $\mathrm{Pz} \mathrm{CS}, 3 \mathrm{~h}$ after injection, the eosin concentration in Pz CS is still of the order of $2 \times 10^{3} \mathrm{mg} / \mathrm{l} /$ injected $\mathrm{kg}$, almost $12 \%$ of the total injected mass of tracer. For the injection of naphtionate, the portion of tracer that remains in the well after a similar period is approximately $4.5 \%$.

Defining a concentration attenuation factor $C^{*}$ between two locations in the aquifer by the ratio between the maximum (modal) concentration $C_{\text {mod }}$ observed on the breakthrough curve at the second point and the concentration in the tracer fluid $C_{\text {inj }}$ injected in the first point allows one to estimate the capacity of the medium to reduce concentration levels by dispersion, dilution and retardation of solutes during their migration in the underground. When the tracer is injected, a first dilution occurs when the tracer fluid mixes with the water in the well. Using the concentration in the injected fluid would thus lead to overestimation of the concentration attenuation factor $C^{*}$. A better estimation is obtained using the maximum of concentration monitored in the injection well (see Fig. 10). Considering this, between $\mathrm{Pz} C S$ and $\mathrm{PC}, C^{*}$ is equal to $1.93 \times 10^{-3}$ for the first tracer test and to $3.44 \times 10^{-3}$ for the second. Despite the different pumping rates applied in the recovery well, the calculated attenuation capacity values are similar. Actually, the reduction of tracer mass loss largely compensates for the dilution in the pumping well by mixing of the traced water with untraced groundwater coming from other directions. From this, the conclusion can be drawn that, between Pz CS and PC, the aquifer has the capacity to reduce concentration levels by a factor of the order of $1 \times 10^{-3}$.

\subsection{Tracer injections performed in the unsaturated zone}

In the unsaturated zone, tracer experiments were performed in order to evaluate transit times from land surface to the water table and to identity mechanisms driving water and solute mobility in the unsaturated zone. Tracers were injected in all the wells screened in the unsaturated zone. Table 6 summarizes information relative to these tracer injections. During the 2 years of monitoring following these injections, pumping was maintained almost permanently at the central well, at a pumping rate ranging between 3.2 and $6 \mathrm{~m}^{3} / \mathrm{h}$. 
Table 6

Synthesis of data and results of tracer tests performed in the unsaturated zone

\begin{tabular}{|c|c|c|c|c|c|c|}
\hline & $\mathrm{Pz}$ CNS & & Pz CGL & & Pz LB & $\mathrm{Pz}$ LS \\
\hline Depth (m) & 19.20 & & 15.80 & & 9.40 & 5.80 \\
\hline Material & Chalk & & Flint conglomerate & & Loess & Loess \\
\hline Tracer & $\mathrm{KCl}$ & $\mathrm{I}^{-}$ & Rhodamine WT & $\mathrm{Li}^{+}$ & Naphtionate & Fluoresceine \\
\hline Time of injection & 8/7/1998, 11:40 & $11 / 11 / 1998,9: 35$ & $8 / 7 / 1998,13: 35$ & 6/11/1998, 10:30 & 8/7/1998, 10:30 & $8 / 7 / 1998,14: 35$ \\
\hline Pumping rate $\left(\mathrm{m}^{3} / \mathrm{h}\right)$ & 6.48 & \multicolumn{5}{|c|}{ Permanent pumping at a rate varying between 3 and $6 \mathrm{~m}^{3} / \mathrm{h}$} \\
\hline Injected mass $(\mathrm{kg})$ & 100 & $7.64(10$ of $\mathrm{KI})$ & 1.1 & 3.275 & 2.5 & 4 \\
\hline Tracer volume $\left(\mathrm{m}^{3}\right)$ & 0.3 & 0.03 & 0.025 & 0.09 & 0.03 & 0.02 \\
\hline Injection/recharge conditions & $\begin{array}{l}\text { Constant recharge: } \\
0.1 \mathrm{~m}^{3} / \mathrm{h}\end{array}$ & No recharge & $\begin{array}{l}\text { First: low recharge } \\
\text { From } 13 / 10 / 1998 \text { : } \\
0.04 \mathrm{~m}^{3} / \mathrm{h} \\
\text { From } 22 / 10 / 1998 \text { : } \\
0.09 \mathrm{~m}^{3} / \mathrm{h}\end{array}$ & $\begin{array}{l}\text { Constant recharge: } \\
0.09 \mathrm{~m}^{3} / \mathrm{h}\end{array}$ & $\begin{array}{l}\text { Low recharge } \\
\text { conditions }\end{array}$ & $\begin{array}{l}\text { Low recharge } \\
\text { conditions }\end{array}$ \\
\hline Time of 1st arrival & $8 / 7 / 1998,16: 55$ & 17/8/1999 & $27 / 11 / 1998$ & 20/3/1999 & $?$ & $?$ \\
\hline Minimum travel time $(\mathrm{h})$ & 5.25 & $\begin{array}{l}8184 \\
\text { (341 days) }\end{array}$ & 3408 (142 days) & 3216 (134 days) & $?$ & $?$ \\
\hline $\begin{array}{l}\text { Unsaturated thickness at the } \\
\text { time of } 1^{\text {st }} \text { arrival }(\mathrm{m})\end{array}$ & $+/-9.15$ & $+/-4.22$ & 12.75 & 10.7 & $?$ & $?$ \\
\hline Maximum velocity $(\mathrm{m} / \mathrm{h})$ & 1.74 & 0.052 & $\begin{array}{l}3.7 \times 10^{-3} \\
(\sim 9 \mathrm{~cm} / \text { day })\end{array}$ & $\begin{array}{l}3.3 \times 10^{-3} \\
(\sim 8 \mathrm{~cm} / \text { day })\end{array}$ & $?$ & $?$ \\
\hline Time of modal restitution & 9/7/1998, 00:10 & $9 / 6 / 2000 ?$ & $11 / 5 / 1999$ & $22 / 7 / 1999$ & $?$ & $?$ \\
\hline Modal transit time $(\mathrm{h})$ & 11.5 & $\begin{array}{l}15,312 \\
\text { (638 days)? }\end{array}$ & 7368 (307 days) & 6192 (258 days) & $?$ & $?$ \\
\hline Mean unsaturated thickness (m) & $+/-9.15$ & $+/-3.7$ & 11.27 & 10.03 & $?$ & $?$ \\
\hline Modal velocity $(\mathrm{m} / \mathrm{h})$ & 0.788 & $\begin{array}{l}2.42 \times 10^{-4} \\
(0.58 \mathrm{~cm} / \text { day })\end{array}$ & $\begin{array}{l}1.53 \times 10^{-3} \\
(3.67 \mathrm{~cm} / \text { day })\end{array}$ & $\begin{array}{l}1.625 \times 10^{-3} \\
(3.90 \mathrm{~cm} / \text { day })\end{array}$ & $?$ & $?$ \\
\hline$C^{*}=C_{\mathrm{mod}} / C_{\mathrm{inj}}$ & $\begin{array}{l}\mathrm{K}^{+}: 2.97 \times 10^{-5} \\
\mathrm{Cl}^{-}: 3.66 \times 10^{-5}\end{array}$ & $6.0 \times 10^{-7}$ & $2.0 \times 10^{-7}$ & $1.2 \times 10^{-6}$ & $?$ & $?$ \\
\hline Recovery factor (\%) & $\mathrm{K}^{+}: 3.1, \mathrm{Cl}^{-}: 5.1$ & $+/-26.6$ & $+/-25$ & $+/-30$ & $?$ & $?$ \\
\hline
\end{tabular}


Fig. 11 presents on a time scale the planning of tracer injections and arrivals, together with fluctuations with time of the groundwater table at Pz12. For the sake of clarity in the text, the chronology of injection operations is provided.

\subsubsection{Description of injections performed in the unsaturated chalk (Pz CNS)}

In $\mathrm{Pz} \mathrm{CNS}$, a first injection of potassium chloride $(\mathrm{KCl})$ was performed on August 8th 1998. Artificial recharge conditions were created by adding water at a constant rate $\left(2.78 \times 10^{-5} \mathrm{~m}^{3} / \mathrm{s}\right.$, i.e. $\left.0.1 \mathrm{~m}^{3} / \mathrm{h}\right)$ in the well after tracer injection. This led to enhanced

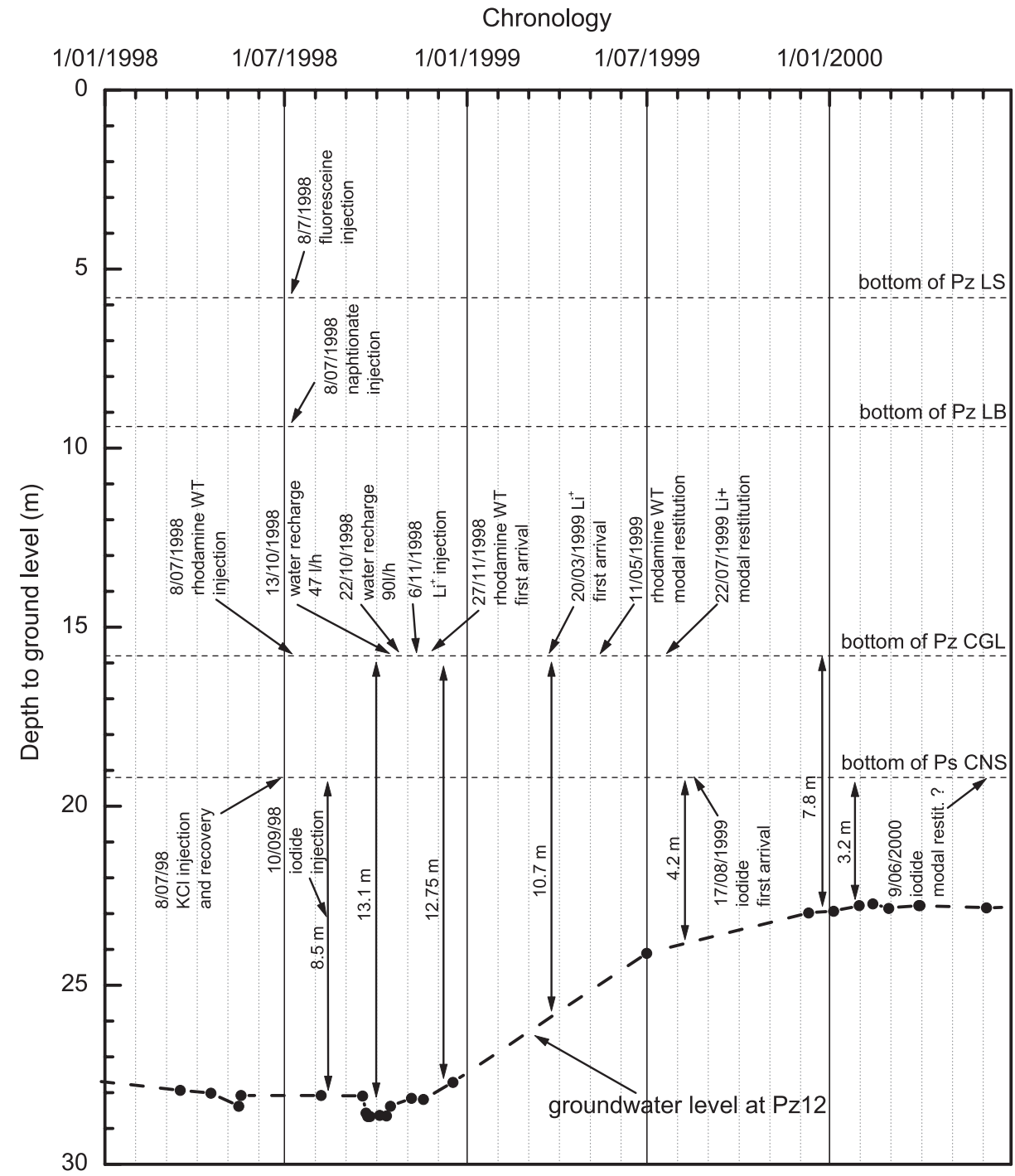

Fig. 11. Planning of tracer experiments performed in the unsaturated zone. 
hydraulic gradient between the injection point and the aquifer and to a higher degree of local saturation in the unsaturated chalk. As the chalk layer is overlain by a thick loess formation, actual recharge conditions are likely to be less intense. To check this, a second tracer injection was performed on September 10th 1998, using potassium iodide (KI), without addition of water after tracer injection. This configuration better reflects actual seepage conditions in the unsaturated chalk. Iodide and chloride being anions, they can be considered as conservative tracers. Fig. 12 presents the resulting breakthrough curves. In the first case, the tracer was detected $5.15 \mathrm{~h}$ after injection, the maximum concentration being reached $11 \mathrm{~h}$ $30 \mathrm{~min}$ after injection. In the second case, transfer times were very different: the tracer was detected only after 340 days while, after 700 days (end of the monitoring campaign), the peak was still not reached even if concentrations seemed to stabilize.

As shown in Fig. 11, the first tracer experiment was performed under low water level conditions, the total thickness of unsaturated chalk crossed by the tracer being approximately $8.5 \mathrm{~m}$. For the second tracer test, due to water rise in the aquifer, the unsaturated thickness of chalk was reduced down to 4 to $3 \mathrm{~m}$. Moreover, water level variations can be subdivided into two contrasting periods: a first period from December 1998 until October 1999, when a monotonic rise is observed and a second period, from November 1999 until August 2000, when a fluctuating trend is observed. This is reflected on the iodide breakthrough curve which shows a monotonic increase of concentration during the first period and a more irregular increase of concentration during the second period. This will be discussed further in more detail.

\subsubsection{Description of injections performed in the conglomerate ( $P z C G L)$}

On July 8th 1998, an injection of rhodamine WT was performed in Pz CGL. Rhodamine WT is known to be affected by sorption in clayey environments. Here, thanks to the high sandy content of the flint conglomerate, it can be expected that the influence of sorption processes is negligible. A daily recharge of 1.2 to 4.41 of water was added, corresponding to a mean water head of $0.3 \mathrm{~m}$ in the bottom of the injection well. No tracer being recovered, it was decided to increase the recharge, on October 13th, 1998, at a rate of $1.3 \times 10^{-5} \mathrm{~m}^{3} / \mathrm{s}$ (i.e. $47 \mathrm{l} / \mathrm{h}$; water head in the well: $8.1 \mathrm{~m}$ ), and 9 days after (on October 22nd, 1998), at a rate of $2 \times 10^{-5} \mathrm{~m}^{3} / \mathrm{s}$ (i.e. $90 \mathrm{l} / \mathrm{h}$; water head in the well: $9.9 \mathrm{~m}$ ).

As for the unsaturated chalk, it could be expected from recharge conditions to have a significant influence on downward tracer migration. To check this, on November 6th 1998, it was decided to perform an injection of lithium chloride in Pz CGL, under prevailing recharge conditions $\left(2 \times 10^{-5} \mathrm{~m}^{3} / \mathrm{s}\right)$. Lithium is usually considered to show little retardation in the underground. Fig. 13 presents the breakthrough curves measured at the central well.

Rhodamine WT tracer was finally detected 140 days after injection. The maximum concentration was reached after 307 days (210 days after the first increase of recharge in Pz CGL). The breakthrough curve also shows clear sharp, secondary peaks, induced most probably by temporarily stops of the pump (freezing conditions, earthworks close to the experimental site). The lithium tracer was detected 134 days after injection, the maximum concentration being observed after 258 days. This breakthrough curve is not affected by interruptions to pumping since, at that time, the tracer was still migrating down in the unsaturated zone. 
(a)

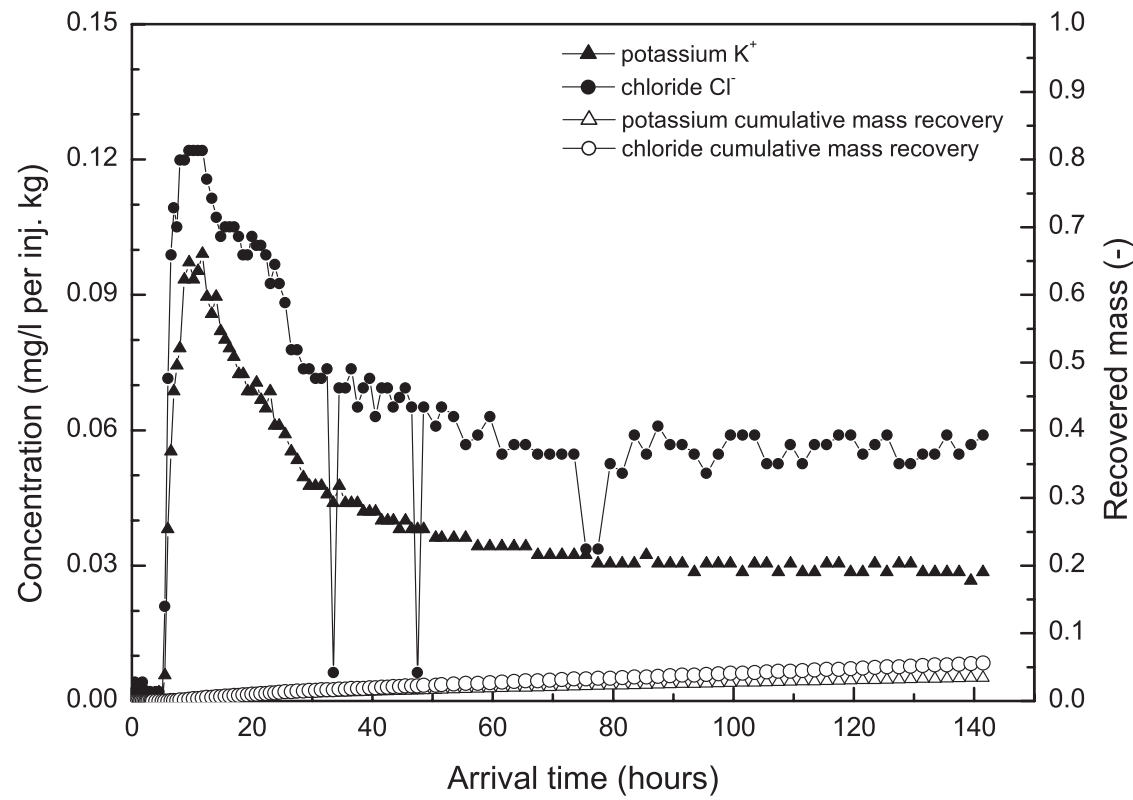

(b)

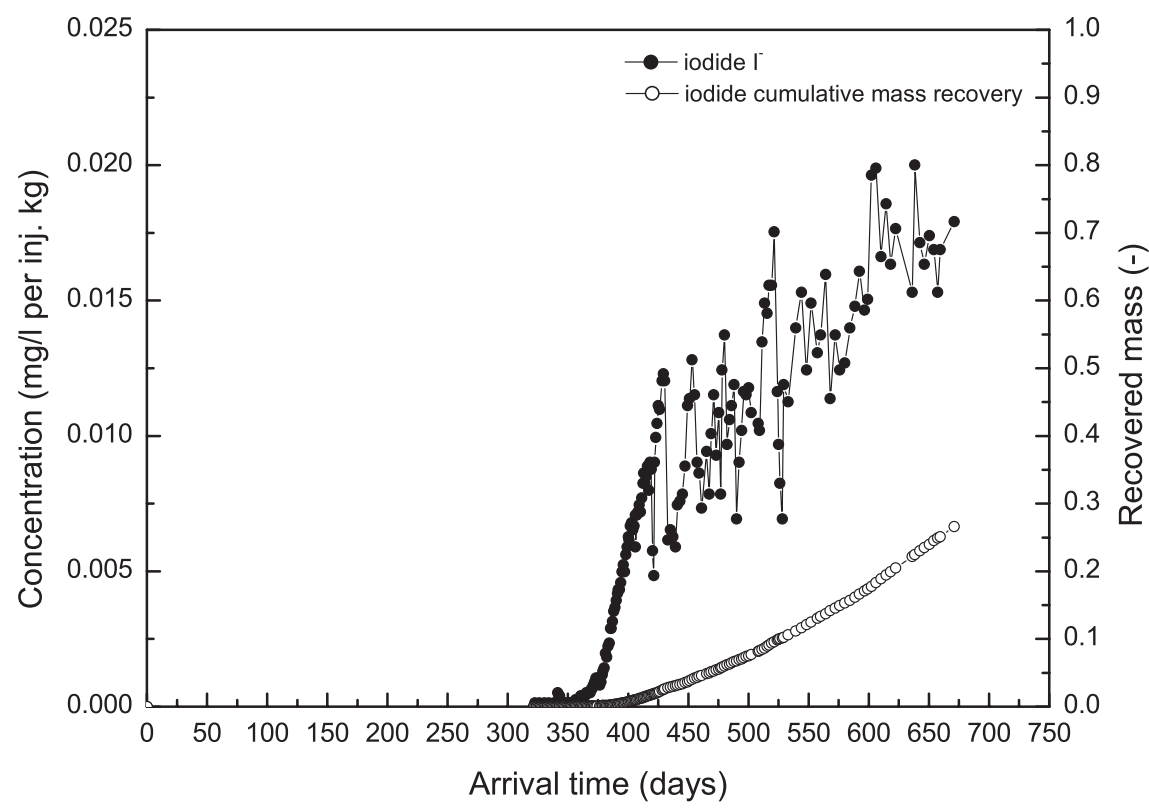

Fig. 12. Breakthrough curves of tracers injected in Pz CNS. 


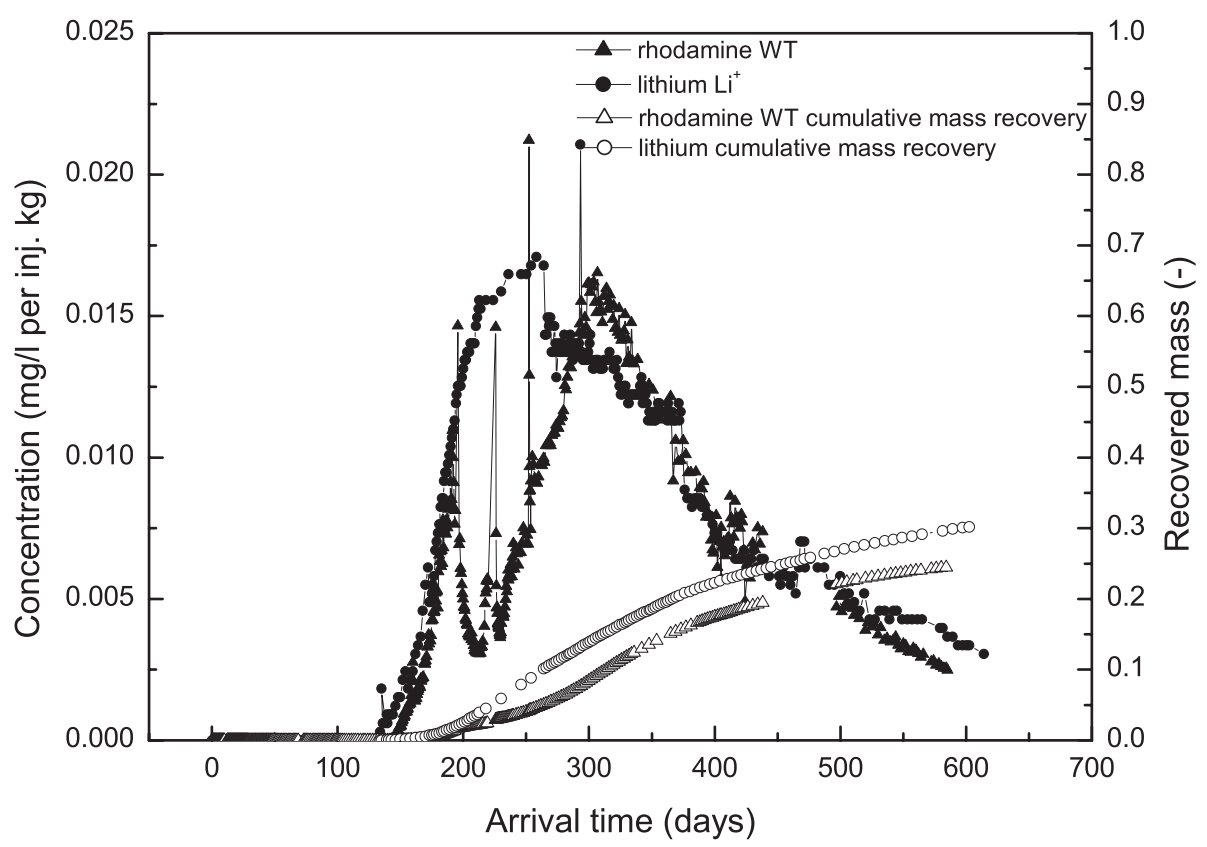

Fig. 13. Breakthrough curves of tracers injected in Pz CGL.

From Fig. 11, it appears that both tracers were injected under low water level conditions, while first arrivals were observed during the period of rise in the groundwater level. The initial tracing distance separating the bottom of Pz CGL and the aquifer level $(13.1 \mathrm{~m})$ was reduced to $12.75 \mathrm{~m}$ and to $10.7 \mathrm{~m}$ for the first arrivals of rhodamine WT and lithium, respectively. Considering these water level variations, it appears that the maximum migration velocity of rhodamine WT is slightly higher $\left(1.04 \times 10^{-6} \mathrm{~m} / \mathrm{s}\right.$, i.e. $9 \mathrm{~cm} /$ day) than for lithium $\left(9.26 \times 10^{-7} \mathrm{~m} / \mathrm{s}\right.$, i.e. $8 \mathrm{~cm} /$ day $)$. In contrast, lithium shows a modal velocity slightly higher $\left(4.5 \times 10^{-7} \mathrm{~m} / \mathrm{s}\right.$, i.e. $3.9 \mathrm{~cm} /$ day $)$ than rhodamine WT $\left(4.25 \times 10^{-7} \mathrm{~m} / \mathrm{s}\right.$, i.e. $3.67 \mathrm{~cm} /$ day $)$.

\subsubsection{Description of the injections performed in the loess (Pz LB and Pz LS)}

On July 8th, 1998, injections of naphtionate and fluoresceine were performed in Pz LB and LS, respectively. Until mid-November 1998, a daily recharge of water was added (approx. 1 1/day), corresponding to a water head of $30 \mathrm{~cm}$ in the wells. From the injection until the end of the monitoring campaign, no arrival of these tracers was detected at the central well.

\subsubsection{Discussion of tracer experiments performed in the unsaturated zone}

Injections performed in $\mathrm{Pz} C \mathrm{CNS}$ were clearly affected by recharge conditions. In $\mathrm{Pz}$ CGL, the influence of recharge conditions is not so evident. Though, the transit time of tracers injected in Pz CGL is shorter than the transit time of iodide injected in the chalk. These observations may seem contradictory. If recharge conditions do not have any 
influence, tracers injected in Pz CGL should have taken a longer time to reach the aquifer, because they also had to migrate across the chalk. The explanation is not straightforward; however, it could be related to the local heterogeneity of the chalk around the central well.

As for the saturated zone, a concentration attenuation factor can be computed. Since there is no dilution in the injection wells, the concentration in the tracer fluid can be compared directly to the maximum concentration observed on the breakthrough curve. For tracer injections performed in $\mathrm{Pz}$ CGL, the calculated $C^{*}$ ranges from $1.2 \times 10^{-6}$ to $2 \times 10^{-7}$, while in the chalk, it varies from $3 \times 10^{-5}$ (with recharge) to $6 \times 10^{-7}$ (without recharge). These values represent the "global" concentration attenuation factor in the combined unsaturated-saturated zone. The concentration attenuation factor relative to the transit of tracers across the unsaturated zone alone can be estimated by dividing the "global" concentration attenuation factor by the concentration attenuation factor previously computed in the saturated zone, i.e. approximately a factor 1/1000 (see Section 3.4.2). This shows that even without dilution in groundwater, the capacity of the unsaturated zone to reduce concentration levels is appreciable, ranging from $1 \times 10^{-2}$ to $1 \times 10^{-4}$.

Tracers injected in the loess sediments were not detected during the sampling period (2 years). They were most probably still migrating downward in the unsaturated zone. This does not contradict the estimation of a nitrate downward migration of $1 \mathrm{~m} /$ year (Dautrebande et al., 1999).

\section{General discussion}

\subsection{Water recharge and solute migration in the unsaturated zone}

From field observations and measurements, first conclusions can be drawn on water recharge and solute migration mechanisms. In the loess, water contents are mostly at field capacity and recharge mechanisms are mainly controlled by gravitational flows, during rainy events. From the absence of any recovery of the tracers injected in the loess, the conclusion can be drawn that no preferential flows seem to affect water and solute downward migration in this layer.

In the flint conglomerate, lower water contents are observed, in relation with the high sandy content. Tracers injected in this layer do not seem to be significantly affected by recharge conditions. Downward migration in this layer is thus also probably driven by gravitational flows related to previous rainy events.

In the chalk, water contents seem to be close to saturation. From the tracer test results, it appears that recharge conditions have a tremendous effect on the mechanisms driving solute migration in the chalk. This is discussed in the next section.

\subsection{Hydrodynamic and hydrodispersive behaviour of the chalk under variable recharge conditions}

The most significant observation drawn from the field experiments is the strong contrast in terms of travel times between tracer injections performed in the unsaturated 
chalk with and without water recharge. Tracer arrival times are about three orders of magnitude smaller when forced gradient conditions prevail compared to natural infiltration conditions.

To explain this particular behaviour, the dual porosity-dual permeability of the chalk has to be invoked. The chalk is characterized by a high porosity and a low hydraulic conductivity at saturation. At Bovenistier, matrix porosities ranging from $38 \%$ to $51 \%$, and a saturated hydraulic conductivity of $1.3 \times 10^{-8} \mathrm{~m} / \mathrm{s}$ was measured on a chalk matrix sample. This is in accordance with other measurements in the Hesbaye aquifer where matrix porosities range between 30\% and 45\% (Biver, 1993; Hallet, 1999a) or in the United Kingdom, where Cooper et al. (1990) mentioned values up to $40 \%$ or $50 \%$ for the total porosity, Price et al. (1993) gave orders of magnitude of $30 \%$ to $40 \%$ for the matrix porosity and $10^{-9}$ to $10^{-8} \mathrm{~m} / \mathrm{s}$ for the saturated hydraulic conductivity and Barker (1993) considered a porosity of $35 \%$ and a hydraulic conductivity of $10^{-8} \mathrm{~m} / \mathrm{s}$ for the chalk matrix. The porosity associated with the fissures is very low but their contribution to the saturated hydraulic conductivity is predominant. Price et al. (1993) mentioned porosity values associated with fissures of the order to $0.01 \%$ and saturated hydraulic conductivity values ranging between $10^{-5}$ and $10^{-3} \mathrm{~m} / \mathrm{s}$. Barker (1993) made a distinction between microfissures (primary fissuration) characterized by hydraulic conductivity values ranging between $10^{-7}$ and $10^{-5} \mathrm{~m} / \mathrm{s}$ and representing approximately $1 \%$ of the chalk rock, and a secondary fissure network showing hydraulic conductivities of the order of $10^{-3} \mathrm{~m} / \mathrm{s}$. Here, pumping tests and infiltration tests show similar orders of magnitudes for the hydraulic conductivity of the fissured chalk $\left(10^{-5}-10^{-4} \mathrm{~m} / \mathrm{s}\right)$.

From the observations drawn in Bovenistier, it appears that, just like in the saturated zone, the structural characteristics of the chalk play a significant role in the unsaturated zone. Hence, the matrix porosity is made up of a large number of pores having dimensions of the order of $1 \mu \mathrm{m}$. Due to that, capillary tensions prevailing in the matrix are very high, with the direct consequence that, under regular hydrological conditions, the matrix water content is always close to saturation. Capillary forces also explain the quasi-immobility of water in the matrix. Price et al. (1993) estimate the capillary rise in the chalk matrix to 30 $\mathrm{m}$. At Bovenistier, well neutron logs provide an estimation of $4 \mathrm{~m}$. However, the gammagamma logs indicate that the upward extension of the capillary rise may be limited by the occurrence of a more fractured level in the chalk. The van Genuchten parameter $\alpha$ is representative of the inverse of the capillary rise. From the mean value obtained for this parameter on chalk samples, an estimation of $10 \mathrm{~m}$ is found, in agreement with the literature. Values are a bit lower than usual, probably in relation with stronger alteration of the chalk in the fluctuating zone of the groundwater table.

Fissures are characterized by larger openings. Due to that, capillary forces are not so developed. Assuming a mean opening of about $50 \mu \mathrm{m}$, Price et al. (1993) estimate a maximum capillary rise of $0.5 \mathrm{~m}$ in the fractures. This means that, under natural recharge conditions, fissures are most often empty and inactive. Practically, if the net infiltration is below the matrix saturated hydraulic conductivity, the recharge rate is not sufficient to keep the fissure network at saturation. Water is thus confined in the matrix, moving from one fissured block to another, through contact points playing the role of hydraulic bridges (Wang and Narasimhan, 1985). The average velocity of downward migration of water and 
solutes in the unsaturated chalk is very low, governed by the low hydraulic conductivity and the large porosity of the matrix.

During periods of intense water recharge, it may occur that the matrix becomes fully saturated. From that moment, the excess of water is free to infiltrate through the fissure network. The fissures having a very low water capacity, the water content is able to increase rapidly, leading consequently to a quick increase of the chalk hydraulic conductivity. Water then flows mostly through the fissure network and, compared to that, water located in the matrix can be assumed as immobile, its role being limited to the storage and release of water and solutes. Under such conditions, any contaminant present in the infiltrating water is able to reach very quickly the water table by fast downward migration through the fissure network.

This conceptualization of the dynamic behaviour of chalk hydraulic and hydrodispersive properties provides an explanation of the results of tracer tests performed in the chalk. For the injections performed in the saturated zone and in the unsaturated chalk under intense recharge conditions, the fissure network is active. Tracers migrate at high speed through the fissures while they are subject to temporary retardation by migration in the immobile water located in the matrix. For the injection performed in natural infiltration conditions in the unsaturated chalk, the fissure network remained inactive, the tracer migration occurring through the matrix, at far lower speed.

To transcribe mathematically this conceptual model, Brouyère (2001) has developed an approach that relies on two main concepts. A new formulation, close to that of Ross and Smetten (1993) or Durner (1994), is used to model the unsaturated properties of the fissured chalk to consider with greater accuracy the bi-modal distribution of the chalk porosity (matrix porosity and fissure porosity). To account for the variation of effective porosity according to recharge conditions and saturation degree of the chalk, a partitioning algorithm similar to that proposed by Zurmühl and Durner (1996) is used.

\subsection{Dynamics of concentrations in the chalk aquifer}

In several observation wells located in the Hesbaye aquifer, nitrate concentration variations may be related to water level fluctuations. To explain this, Hallet (1999b) proposed the following mechanism. Nitrates spread over the land surface progressively infiltrate across the unsaturated zone. This input is characterized by relatively high concentrations of contaminants, ranging from 50 to $200 \mathrm{mg} / \mathrm{l}$. Under low groundwater level conditions, the contamination front is disconnected from the saturated zone of the aquifer. It migrates slowly, downward through the unsaturated chalk matrix. Meanwhile, nitrates present in the saturated zone are diluted by dispersion and mixing in the groundwater, so that a lower level of contamination (around $35 \mathrm{mg} / \mathrm{l}$ ) is found. In the Hesbaye aquifer, sampling operations performed during groundwater recession periods usually show lower nitrate concentrations in the saturated zone. When groundwater levels rise, the contamination front is quickly reached and washed: the contamination source is re-activated and nitrate concentrations are likely to increase rapidly in the saturated zone. Sampling operations performed in rising groundwater conditions usually show higher nitrate concentrations. 
At Bovenistier, concentration fluctuations observed on breakthrough curves of iodide (injected in the unsaturated chalk) and rhodamine WT (injected in the conglomerate) confirm these mechanisms and explanations. The iodide breakthrough curve shows a monotonic increase with time during the period of water level rise and a fluctuating trend when groundwater levels stabilized and started to fluctuate. The rhodamine WT breakthrough curve shows steep concentration peaks, all of them being associated with temporary stops of pumping operations at the central well. During these periods, water level rose, washing the tracer in the unsaturated zone, inducing high concentration peaks after pumping operations were restarted. The lithium tracer was probably not affected by pump stops because, at that time, it was still migrating down in the upper part of the unsaturated zone.

\subsection{Vulnerability of the chalk to contamination}

Vulnerability studies are often performed in order to evaluate aquifer sensitivity to contamination. Very often, relatively empirical methods are used in order to differentiate zones in the groundwater basin with respect to their vulnerability to contaminations occurring at the land surface. Brouyère et al. (2001) have proposed to evaluate the aquifer vulnerability considering the following physical criteria: the time needed by the contaminant to migrate from the origin of the pollution (usually the land surface) to the aquifer surface and the capacity of the underground medium to attenuate pollution concentrations and duration. The vulnerability associated to one location in the basin is higher as the contaminant transit time from that location to the aquifer is shorter, the concentration attenuation is less pronounced or the contamination duration is potentially longer.

Based on tracer test results obtained here, estimations can be assessed for transit times (based on tracer first arrivals) and concentration attenuation capacity (based on computed concentration attenuation factors). Apart from providing useful information on the underground hydrodynamic and hydrodispersive behaviour, tracer tests could be very useful for quantification and validation purposes in the development and assessment of a "physically based" aquifer vulnerability assessment.

From the tracer test results, it appears that the vulnerability of the chalk to contamination is strongly dependent on the existence or not of a protective cover. Here, due to the presence of a thick layer of loess sediments, the water recharge rate applied at the top of the chalk is strongly attenuated. Fissures remain inactive and the downward migration of water and contaminants across the matrix is very slow. Under intense recharge conditions, tracers travel across the unsaturated chalk in a few hours while, in natural recharge conditions, they need almost 1 year to cross the reduced thickness of unsaturated chalk. This enhances the possibilities for attenuation mechanisms to reduce contamination levels during the migration across the unsaturated chalk. This is reflected in the concentration attenuation factor which is of the order of $10^{-5}$ when intense recharge conditions prevail and $10^{-7}$ when natural recharge conditions prevail. If the chalk was outcropping or just covered by more pervious materials, under intense recharge conditions, it is likely that fissures would become frequently saturated, driving contaminants at high speed downward to the aquifer and reducing the capacity for natural attenuation in the unsaturated zone. The chalk would thus be more vulnerable in this situation. 


\section{Conclusions}

Detailed field investigations performed at Bovenistier in the Hesbaye region have provided a very complete data set for understanding and quantifying water recharge and solute leaching processes across the unsaturated zone overlying the Hesbaye fissured chalk aquifer.

In the loess and the flint conglomerate, water recharge mechanisms are dominated by gravitational flows, without evidence of preferential flows. The average velocity of solute downward migration is very low. An estimation of $1 \mathrm{~m} /$ year across the loess was given by Dautrebande et al. (1999). Because of the presence of overlying loess and conglomerate, the water infiltration rate at the top of the unsaturated chalk is strongly attenuated compared to the actual recharge at the ground surface. It is therefore not sufficient to keep the fissure network at saturation and water infiltrates slowly downward across the matrix. It has been observed that solutes migrate at a velocity of the order of $1 \mathrm{~m} / \mathrm{year}$, this solute transport being largely influenced by the low hydraulic conductivity and the large porosity of the matrix.

If the chalk was outcropping, water recharge and solute migration would be quite different. As soon as the net infiltration rate is higher than the saturated hydraulic conductivity of the matrix, the excess water is free to infiltrate rapidly through the fissure network. In these conditions, any contaminant present in the infiltrating water is able to reach very quickly the water table. Compared to that, groundwater located in the matrix can be assumed as immobile, contributing only to storage and release of water and solutes, just like in the saturated zone.

Apart from providing a good understanding and conceptualization of the hydrodynamic and hydrodispersive behaviour of chalk under variably saturated conditions, this experiment gives new information on the dynamics of nitrate concentrations in the Hesbaye aquifer. It shows that variations in groundwater levels affect concentration evolutions in the aquifer for tracers injected in the unsaturated zone. During periods of groundwater rise, tracers (or contaminants) migrating downwards in the unsaturated zone are washed, inducing an increase in concentration in the aquifer. Contrarily, when the groundwater levels drop, the contamination front is disconnected from the saturated zone and concentrations decrease in the aquifer.

Finally, based on the experiments, it can be concluded that the vulnerability of the chalk aquifer to contaminations occurring at the land surface is strongly dependent on the existence of a protective cover. Due to that, the recharge rate at the top of the unsaturated chalk is attenuated and contaminants migrate slowly down through the matrix, enhancing the possibilities for natural attenuation.

One of the next steps of this research is to model these results in order to confirm hypotheses and to quantify parameters associated with identified processes.

\section{Acknowledgements}

These field experiments were performed under the scope of a research project funded by the General Division for Natural Resources and Environment from the Ministry of 
Environment and Agriculture of the Walloon Region in Belgium. S. Brouyère also benefited from a 4-year PhD grant provided by the National Funds for Scientific Research of Belgium. The triaxial cell measurements were performed by the Laboratory of Geomaterials (Dr. Chr. Schroeder) at the University of Liège. Measurements of physical and hydraulic properties of unsaturated formations were performed by the Agricultural Hydraulics Unit (Prof. S. Dautrebande), from the Faculty of Agronomy in Gembloux, Belgium. Nitrate was analyzed by the Center of Agronomical Research of Gembloux (Vegetal Production Department). The lenacil pesticide was analyzed by Prof. Copin from the Faculty of Agronomy in Gembloux.

The authors would like to thank John Barker, from the University College of London, and the two reviewers R. Therrien and T.J. Besien for their helpful comments and corrections that helped to improve the quality of this manuscript.

\section{References}

Allen, D.J., Price, M., 1990. Hydraulic conductivity of the chalk at shallow depths in north-west Norfolk, UK. In: Telford, T. (Ed.), Chalk, pp. 577-581 (London).

Barker, J.A., 1993. Modelling groundwater flow and transport in the chalk. The Hydrogeology of the Chalk of North-West Europe. In: Downing, R.A., Price, M., Jones, G.P. (Eds.), Oxford Science Publ., Clarendon Press, Oxford, UK, pp. 59-66.

Barker, J.A., Foster, S.S.D., 1981. A diffusion exchange model for solute movement in fissured porous rock. Q. J. Eng. Geol. 14, 17-24.

Biver, P., 1993. Etude phénoménologique et numérique de la propagation de polluants miscibles dans un milieu à porosité multiple (phenomenological and numerical study of miscible contaminant propagation in a multiporosity medium), in French, PhD thesis, University of Liège, Faculty of Applied Sciences. 389 pp.

Brouyère, S., 2001. Etude et modélisation du transport et du piégeage des solutés en milieu souterrain variablement saturé (study and modelling of transport and retardation of solutes in variably saturated media), in French, PhD Thesis, University of Liège, Faculty of Applied Sciences. 572 pp.

Brouyère, S., Jeannin, P.-Y., Dassargues, A., Goldscheider, N., Popescu, I.-C., Sauter, M., Vadillo, I., Zwahlen, F., 2001. Evaluation and validation of vulnerability concepts using a physically based approach, proceedings of the "7e Colloque d'Hydrologie en Pays Calcaire et en Milieu Fissuré", Besançon., 20-22 sep. 2001. Sci. Tech. Environ., Mém. Hors. Ser. 13, 67-72.

Cooper, J.D., Gardner, C.M.K., MacKenzie, N., 1990. Soil water control on recharge to aquifers. J. Soil Sci., 41.

Dassargues, A., Monjoie, A., 1993. The Chalk in Belgium. The Hydrogeology of the Chalk of North-West Europe. In: Downing, R.A., Price, M., Jones, G.P. (Eds.), Oxford Science Publ., Clarendon Press, Oxford, UK, pp. $153-269$.

Dautrebande, S., Dewez, A., Hallet, V., Guiot, J., Rouxhet, F., Monjoie, A., 1996. Programme action Hesbaye. Final Report of the EC-Life Project (167 pp.).

Dautrebande, S., Dewez, A., Casse, C., Hennebert, P., 1999. Nitrate leaching at regional scale with EPIC: an implicit example of a hydrotope model concept. European Agric. Eng. Soil and Water Interest Group. Leuven, Belgium, pp. $765-774$.

Durner, W., 1994. Hydraulic conductivity estimation for soils with heterogeneous pore structure. Water Resour. Res. 30 (2), $211-223$.

Guiot, J., Goffart, J.P., Destain, J.P., 1992. Le dosage des nitrates dans le sol. Bull. Rech. Agron. Gembloux 27 (1), 61-74.

Hallet, V., 1999a. Etude de la contamination de la nappe aquifère de Hesbaye par les nitrates: hydrogéologie, hydrochimie et modélisation mathématique des écoulements et du transport en milieu saturé (Contamination of the Hesbaye aquifer by nitrates: hydrogeology, hydrochemistry and mathematical modeling), in French, PhD Thesis, University of Liège, Faculty of Sciences. 361 pp.

Hallet, V., 1999b. Etude hydrochimique relative à l'évolution et à la répartition des nitrates dans la nappe aquifère 
de Hesbaye (Belgique) (Hydrochemical study of the evolution and spatial distribution of nitrates in the Hesbaye aquifer in Belgium). Trib. Eau 600-601 (4/5), 51-58.

Hvorslev, M.J., 1951. Time lag and soil permeability in groundwater observations. Bulletin, vol. 36. United States Watering Experimental Station, Vicksburg, MS.

Käss, W., 1998. Tracing Techniques in Geohydrology. In: Balkema, A.A. (Ed.), Brookfield, Rotterdam. 581 pp.

Mabillot, A., 1989. Le forage d'eau, Guide pratique. Academ. Agric., France. 237 pp.

Mohanty, B.P., van Genuchten, M.Th., 1996. An integrated approach for modeling water flow and solute transport in the vadose zone. Application of GIS to the Modeling of Non-Point Source Pollutants in the Vadose Zone. In: Corwin, D.L., Loague, K. (Eds.), Soil Sci. Soc. Am. Special Publ., vol. 48, pp. 217-233. Madison, WI.

Monjoie, A., Dautrebande, S., Frankinet, M., Copin, A., 2000. Etude phénoménologique de la propagation d'une substance miscible en milieu non saturé. Application au transport des nitrates vers la nappe aquifère de Hesbaye (Phenomenological study of miscible contaminant transport across the unsaturated zone. Application to nitrate transfer to the Hesbaye aquifer (in French). Report LGIH RW/2000-02. University of Liège, Belgium.

Price, M., Downing, R.A., Edmunds, W.M., 1993. The chalk as an aquifer. The Hydrogeology of the Chalk of North-West Europe. In: Downing, R.A., Price, M., Jones, G.P. (Eds.), Oxford Science Publ, Clarendon Press, Oxford, UK, pp. 35-58.

Repsold, H., 1989. In: Castany, G., Groba, E., Romijn, E. (Eds.), Well Logging in Groundwater Development, International Contributions to Hydrogeology. IAH, vol. 9. Verlag, Hannover, Germany, p. 136.

Ross, P.J., Smetten, R.J., 1993. Describing soil hydraulic properties with sums of simple functions. Soil Sci. Soc. Am. J. 57, 26-29.

Stephens, D.N., Neuman, S.P., 1982. Vadose zone permeability tests: summary. J. Hydraul. Div., Proc. Am. Soc. Civil Eng. 108, 623-639.

van Genuchten, M.Th., 1980. A closed-form equation for predicting the hydraulic conductivity of unsaturated soils. Soil Sci. Soc. Am. J. 44, 892-898.

van Genuchten, M.Th., Leij, F.J., 1992. On estimating the hydraulic properties of unsaturated soils. Proceedings of the International Workshop, Indirect methods for Estimating the Hydraulic Properties of Unsaturated Soils, U.S. Salinity laboratory and University of California, Riverside, pp. 1-14.

Wang, J.S.Y., Narasimhan, T.N., 1985. Hydrologic mechanisms governing fluid flow in a partially saturated, fractured, porous medium. Water Resour. Res. 21 (12), 1861-1874.

Wösten, J.H.M., 1997. Pedotransfer functions to evaluate soil quality. In: Gregorich, E.G., Carter, M.R. (Eds.), Soil Quality for Crop Production and Ecosystem Health. Developments in Soil Science, vol. 25. Elsevier, Amsterdam, pp. 221-245.

Younger, P.L., Elliot, T., 1995. Chalk fracture system characteristics: implications for flow and solute transport. Q. J. Eng. Geol. 28, S39-S50.

Zurmühl, T., Durner, W., 1996. Modeling transient water and solute transport in biporous soil. Water Resour. Res. $32(4), 819-829$. 